\title{
ENDEAVOR RESEARCH INTO EVOLVING PARADIGMS AROUND OPHIOLITES: THE CASE OF THE OCEANIC IGNEOUS COMPLEXES OF COSTA RICA
}

\author{
Guillermo E. Alvarado ${ }^{1,2^{*}}$, Percy Denyer ${ }^{1}$ \& Esteban Gazel ${ }^{3}$ \\ ${ }^{1}$ Escuela Centroamericana de Geología, Universidad de Costa Rica, \\ ${ }^{2}$ Área de Amenazas y Auscultación Sísmica y Volcánica; \\ Instituto Costarricense de Electricidad, San José, Costa Rica \\ ${ }^{3}$ Department of Geological Sciences, Rutgers University \\ *Autor para contacto: galvaradoi@ice.go.cr
}

(Recibido: 10/9/2008; aceptado: 20/07/2008)

\begin{abstract}
ABTRACT: More than one century of studies were done on the radiolarite-igneous ("ophiolitic") complexes in Costa Rica that range from Jurassic to Eocene. These studies can be grouped in four main stages of knowledge: 1) from 1904 to 1957 were recognized the cherts, and the mafic and ultramafic igneous complexes, the first regional maps were done, and the first time were recognized ellipsoidal basalts, now widely known as pillow lavas. 2) From 1958 to 1978, the complexes were seen under the concept of the association of ophiolites (serpentine, gabbro, diabase, basalts, and related rocks), and interpreted the radiolarites as deep-sea sediments. This stage is characterized by the seminal work of Gabriel Dengo and by the first geochemical analyses in the framework of the plate tectonics. 3) From 1979 to 1994, a huge amount of geochemical data, paleontological and $\mathrm{K} / \mathrm{Ar}$ ages were published and it was the stage of more controversial papers. Their interpretation varied for the same locality (i.e. Nicoya Peninsula) from a relative simple stratigraphic model to a very complex nappe slices, and from a simple tectonic evolution (in situ and formed by a mid-oceanic ridge volcanism) to a multistage evolution (terrains, and mid-oceanic ridge, aseismic ridge, intraplate and island arc volcanism). The situation was similar in the other Costa Rican oceanic complexes. 4) From 1995 to present, the panorama and mutual agreement between the different groups was clearer. This stage is characterized by joint collaboration, the use of modern laboratory techniques as $\mathrm{Sr}, \mathrm{Nd}$, and $\mathrm{Pb}$ isotopes, major, trace and complete rare earth elements, ${ }^{40} \mathrm{Ar} /{ }^{39} \mathrm{Ar}$ dating, and volcanological criteria, together with detailed field mapping. The main new result of these studies was that the radiolarites (164-84 Ma) in the Nicoya Peninsula were significatively older than the basic igneous rocks (140-84 $\mathrm{Ma})$, indicating a complex magmatic event intruding and erupting into the thick sedimentary sequence. For other areas, like Santa Elena Peninsula, Tortugal, Herradura and Quepos, the picture on these oceanic complexes are more or less clear. In the case of Osa-Golfito-Burica area, more studies are necessary. In general, the detailed field mapping is a powerful tool in combination with the modern techniques. The similarity in age, petrology, geochemistry and tectonic
\end{abstract}


context for other oceanic complexes in Guatemala, Antilles and the northern part of South America, is more than a coincidence, they have a similar evolution. Therefore, a multidisciplinary study of the chrono- and bio-stratigraphic relations, together with modern petrology, geochemical and micropaleontology approach is necessary to provide a solid base for a robust plate tectonic reconstruction and geologic history. The aim of this paper is to summarize the historical ideas and data available of the oceanic complexes of Costa Rica, to clarify the evolution of the interpretations and evidences in the frame of the paradigms and the state of the art of knowledge at different moments.

Keywords: Nicoya Complex, ophiolites, oceanic complexes, radiolarites, basalts.

RESUMEN: Por más de un siglo se han realizado estudios sobre los complejos ígneos-radiolaríticos ("ofiolíticos") en Costa Rica, cuyas edades varían del Jurásico al Eoceno. Estos trabajos pueden ser agrupados en cuatro etapas del conocimiento: 1) de 1904 a 1957 se reconocieron los complejos de pedernales, y rocas máficas y ultramáficas, se hicieron los primeros mapas regionales y por primera vez se describieron los basaltos elipsoidales, actualmente conocidos como lavas en almohadilla, 2) Desde 1958 a 1978, los complejos fueron vistos bajo el concepto de ofiolitas (serpentinita, gabro, diabasa, basalto y rocas relacionadas) y se interpretaron las radiolaritas como sedimentos de mar profundo. Esta etapa está caracterizada por el trabajo seminal de Gabriel Dengo y por los primeros análisis geoquímicos en el marco de la tectónica de placas. 3) De 1979 a 1994 se publicó una gran cantidad de análisis geoquímicos, dataciones paleontológicas y radiométricas K/Ar y esa fue la etapa de los artículos más controversiales ya que su interpretacion variaba para la misma localidad (i.e. Península de Nicoya) entre un modelo estratigráfico sencillo a un complejo modelo de varias tajadas de nappes, y desde una evolución tectónica sencilla (in situ y formada por un vulcanismo de la dorsal) a una evolución diversa (terrenos, dorsal, dorsal asísmica, intraplaca y vulcanismo de arco de isla). La situación fue similar en los otros complejos oceánicos de Costa Rica. 4) De 1995 al presente, se ha aclarado el panorama y se ha llegado a un consenso entre los diferentes grupos de investigadores. Esta etapa se caracteriza por la ejecución de proyectos de colaboración entre grupos, el uso de técnicas nuevas de laboratorio como isotópos ( $\mathrm{Sr}, \mathrm{Nd}, \mathrm{y} \mathrm{Pb}$ ), elementos mayores, traza y tierras raras, dataciones de ${ }^{40} \mathrm{Ar} /{ }^{39} \mathrm{Ar}$ y criterios vulcanologicos, junto con mapeo detallado en el campo. Uno de los principales resultados fue el hallazgo de que las radiolaritas (164-84 Ma) en la península de Nicoya fueron significativamente más antiguas que las las rocas ígneas básicas (140-84 Ma), lo que indica un evento magmático complejo de intrusión y erupción en la secuencia sedimentaria. El panorama es más o menos claro para otros complejos oceánicos como Santa Elena, Tortugal, Herradura y Quepos. En el caso del área de Osa-Golfito-Burica, se necesitan más estudios. En general, el mapeo de campo detallado representa una herramienta poderosa en combinación con las técnicas modernas. La similitud en edad, petrología, geoquímica y contexto tectónico de otros complejos oceánicos en Guatemala, Antillas y la parte norte de Sur América, resulta más que una coincidencia, ya que presentan una evolución similar. Por lo tanto, un estudio multidisciplinario de relaciones crono- y bio-estratigraficas, junto con un enfoque moderno petrológico y geoquímico es fundamental para proporcionar una base sólida para la reconstrucción geotectónica y la historia geológica. El objetivo de este artículo es sintetizar las ideas y datos que se han dado históricamente en el estudio de los complejos oceánicos de Costa Rica, a la luz de los paradigmas y la evolución del estado del conocimiento.

Palabras clave: Complejo de Nicoya Complex, ofiolitas, complejos oceánicos, radiolaritas, basaltos.

\section{INTRODUCTION}

Looking into the geotectonic panorama of the Caribbean and its geological significance, the Nicoya Complex sensus latus has occupied a special place in Caribbean geology since its original description by Dengo (1962a). In the 1970's and early 1980's the Nicoya Complex was the focus of extensive research; corresponding with a historical moment in which the ophiolites studies took relevance into the geosciences carpet (e.g. Coleman, 1977). These first studies constituted an effort to understand a very complex picture but with traditional tools, leading to misinterpretation and confusion. Today, the endeavor of more than four decades of research have produced a pile of work, which were done using different methodologies and generate diverse hypotheses and models. In spite of this efforts and the use of the updated technology, nowadays the status of knowledge is still obscure. Thus, many new questions are arising and the oceanic complexes of Costa Rica are still an open field of research.

The oceanic complexes of the Nicoya Peninsula were first mentioned by Sapper (1905) and Romanes (1912a,b) who recognized a greenish igneous sequence. About half a century later this complexes were mapped as a unique unit known as the Nicoya Complex (Dengo, 1962a, b). After that, the Nicoya Complex was for many 
years, generally accepted as a generic name for the oceanic complexes exposed in the Pacific coast of Costa Rica and Panama (Dengo, 1985). Following researches suggested that there were differences in stratigraphy, lithology, age and geochemistry (e.g. Schmidt-Effing, 1980; Berrangé et al., 1989). Also, the ophiolitic model has been commonly applied in relation to the Nicoya Complex outcropping at the Nicoya Peninsula, but in several cases in association to the ultramafics of Santa Elena Peninsula (e.g. De Boer, 1979; Kuijpers, 1980; Berrangé \& Thorpe, 1989; Frisch et al., 1992: Beccaaluva et al., 1999). Now, most of the recent studies on the Costa Rican ophiolites (see reviewers and summary in Denyer et al., 2006; Hauff et al., 1997, 2000; and Hoernle \& Hauff, 2007, and references therein) show that the Nicoya Complex must be restricted only to the Nicoya Peninsula and the southern part of Herradura. Thus, the oceanic complexes and related lithologies at the moment, can be divided into several units of different ages, geotectonic origin and geochemistry, ranging from Middle Jurassic to Miocene.

According to the 'Ophiolite-Manifesto' (Anonymous, 1972), an ophiolitic suite corresponds to a distinctive assemblage of mafic to ultramafic rocks, from botton to top: ultramafic complex, gabbroic complex, mafic sheeted dike complex, mafic volcanic complex and associated rock types, including overlying sedimentary section. An ophiolite may be incomplete, dismembered, or metamorphosed. Although ophiolite generally is interpreted to be oceanic crust (i.e., Coleman, 1977; Le Maitre, 1989) and upper mantle, the use of the term should be independent of its supposed origin (Anonymous, 1972; Wilson, 1989).

According to the Central America literature and the previous definition, the term ophiolite has been commonly used for rocks making up local oceanic basement, including normal and anomalous oceanic lithosphere, which sequence and origin in most of the cases is not well established. The sections include anomalous relationships (not the same as a typical layered structure of the ocean crust), such as basalts, diabases and gabbros that are intruding radiolarites, and the absence of sheeted dikes, or clear relationships between the layered mafic rocks and the other sequences. Most of the sequences have a tectonic contact and/or an intrusive contact, in which the ages of the radiolarites, in most of the cases, are much older than the well-constrained ${ }^{40} \mathrm{Ar} /{ }^{39} \mathrm{Ar}$ ages of the mafic rocks. In spite of that, we recur to the term oceanic igneous complexes in order to include related lithologic associations that have been accreted the ophiolitic more massif sequences.

Although extensive studies were made in the last 30 years in the Costa Rican oceanic complexes, most of them were restricted to the coast, along the Pacific margin; consequently, a paucity of data prevail for compositional variations within individual flow sequence and detailed stratigraphic-volcanological studies everywhere. Therefore future findings could change the conceptual geologic panorama.

The aim of this paper is to summarize the historical ideas and data available of the oceanic complexes of Costa Rica, in order to clarify the evolution of the interpretations and evidences in the frame of the paradigms and the state of the art of knowledge at different moments. We hope that this historical summary could contribute to the understanding of similar problems in ophiolites along South America and the Caribbean region.

\section{GEOTECTONIC FRAMEWORK}

Today the Middle American Trench separates the Cocos and Caribbean plates, and the Panama Fracture Zone separates the Cocos from the Nazca plates. Convergence rates of nearly $10 \mathrm{~cm} \mathrm{y}^{-1}$ have been measured across the Costa Rican segment of the trench (DeMets et al., 1990), and several subduction processes have been proposed that range from smooth subduction off the Nicoya Peninsula to collision, where the Cocos Ridge meets the Middle American Trench (Gardner et al., 1992). The subduction of Cocos Plate underneath the Caribbean Plate is clogged by the Cocos Ridge generated from the Galápagos hotspot, which colides with southern Costa Rica (Fig. 1). The subduction of seafloor roughness generates tectonic erosion and subsidence of the offshore margin wedge (Ranero \& von Huene, 2000; von Huene et al., 1995).

Some controversy exists about the geotectonic setting and the formation and emplacement of 


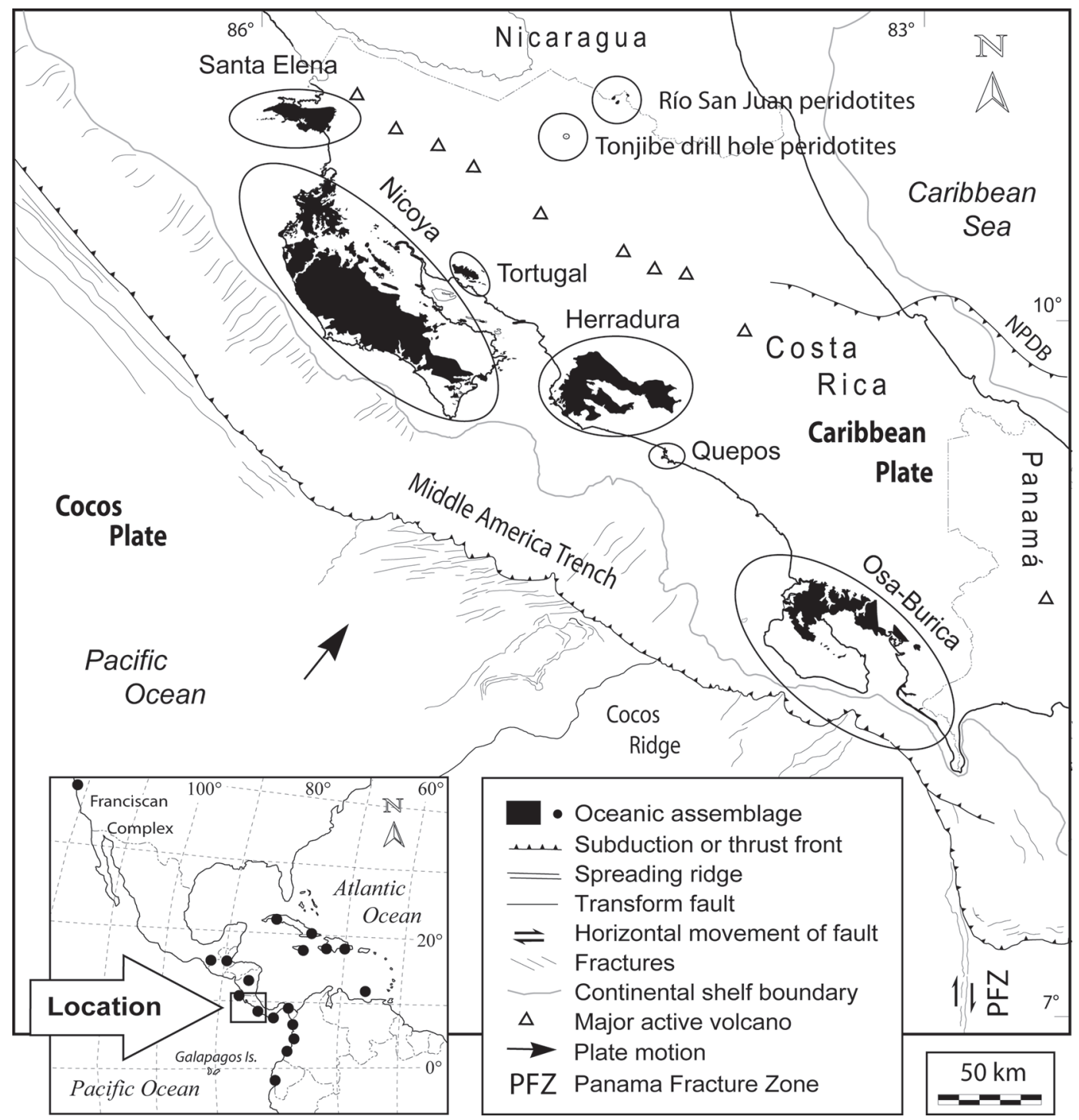

Fig.1: Tectonic setting of the Costa Rican oceanic complexes, and other similar occurrences in Guatemala, Antilles and South America.

the oceanic complexes, which are directly related to the regional models involved in the formation of the Caribbean Plate. Malfait \& Dinkelman (1972), Donnelly et al. (1973), Donnelly (1973) and later Burke et al. (1978) hypothesized that a large part of the present Caribbean Plate was formed in the Pacific as anomalously thick, buoyant crust that later was displaced northeast, between the Americas. Duncan \& Hargraves (1984) suggested that the Galápagos mantle plume was responsible for the thickened Caribbean crust. In opposition to the above models of a general allocthony of the Caribbean, Frisch et al. (1992) and Meschede \& Frisch (1998) proposed an in situ model for the formation of the Caribbean Plateau by the separation of North and South America (for 
Costa Rican oceanic complexes $\quad$ Oceanic crust model column Layer

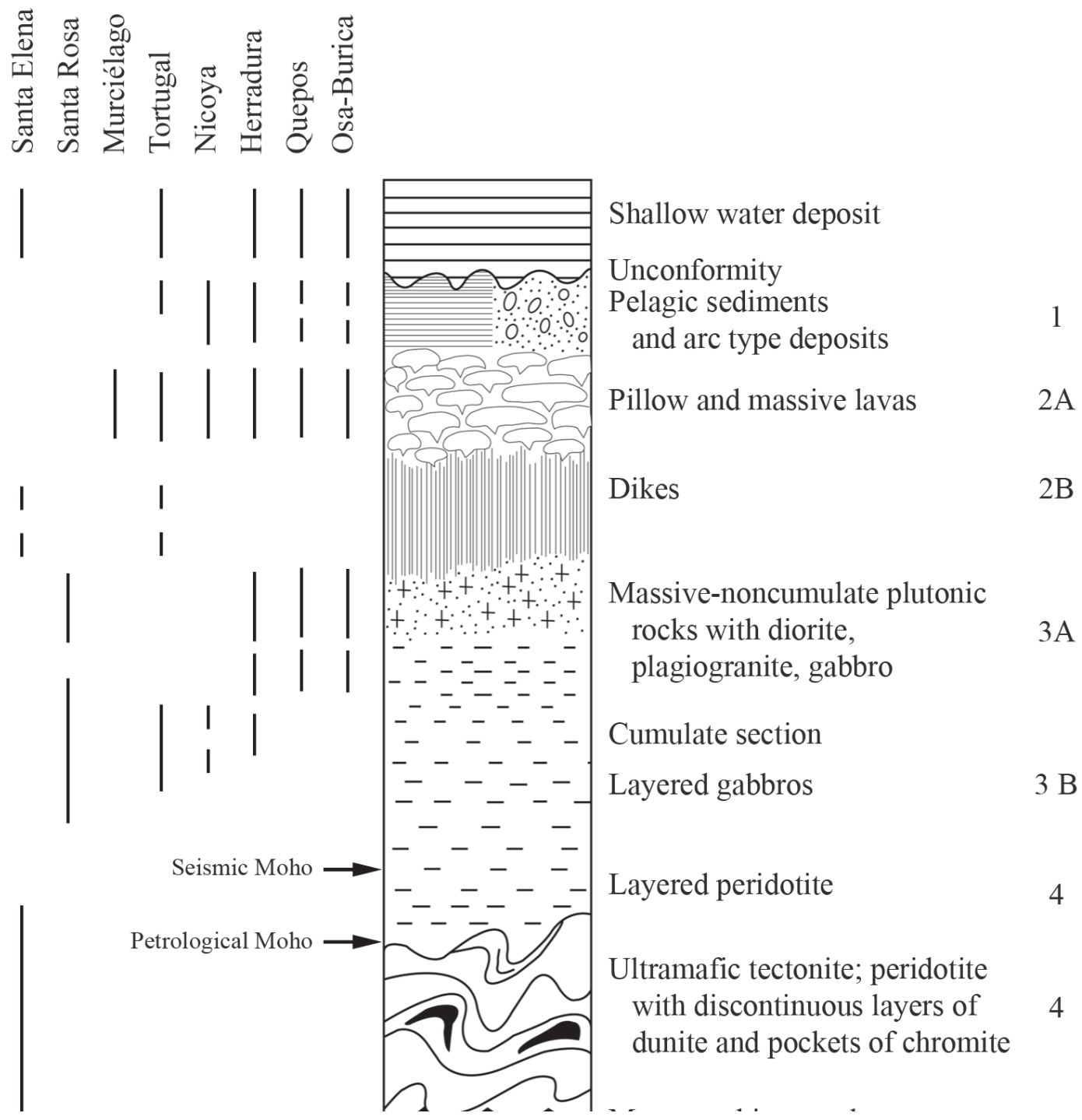

Fig. 2: Comparison of stratigraphy of Costa Rican oceanic complexes with the stratrigraphy of oceanic crust and mantle. Based in Moores (1982) and Wilson (1989).

discussion see Bundschuh \& Alvarado, 2007, and references therein).

The Caribbean Large Igneous Province (CLIP), also known as the "Great Caribbean Flood Basalt Event" or the "Caribbean Sill Event" (Duncan \& Hargraves, 1984; Donnelly et al.,
1990) represents a period of extensive volcanism and intrusive activity between 95 and $72 \mathrm{Ma}$ (with a peak at $\sim 90 \mathrm{Ma}$ ). This magmatic event thickened parts of the present day Caribbean Plate into an oceanic plateau (Sinton et al., 1997; Hoernle et al., 2002). 


\section{COSTA RICAN OCEANIC COMPLEXES}

The Costa Rican oceanic complexes from NW to SE are (1) Santa Elena, (2) Nicoya, (3) Tortugal, (4) Herradura, (5) Quepos, (6) OsaBurica (see Fig. 2). We present an historical summary of conceptual evolution and different models presented thru the last three decades of extensive research (Fig. 1).

\section{Santa Elena}

The Santa Elena peninsula, North Costa Rica, is $30 \mathrm{~km}$ long with hilly terrain and an E$\mathrm{W}$ orientation oblique in relation to other Costa Rican orogenic systems (Fig. 1).

Harrison (1953) first noticed extensive outcrops of peridotites intruded by mafic rocks and overlain by an Upper Cretaceous sedimentary cover. Dengo $(1962 \mathrm{a}, \mathrm{b})$ pointed out the presence of harzburgite and described radiolarites and diabases regarded as lateral equivalents of the Nicoya Complex and suggested that the emplacement of the ultramafic massif was linked to the Clipperton Fracture Zone. The Santa Elena Peninsula comprises ultramafic rocks, generally regarded as a segment of the uppermost mantle forming the basal part of the oceanic crust (Dengo, 1962a, b).

Tournon $(1970,1979)$ found that most of the periodotite of Santa Elena is partially or totally serpentinized lherzolite cut by amphibole-bearing dikes. De Boer (1979) interpreted the peridotitic massif as the lowest unit of a "Nicoya Ophiolitic Complex". Radiolarites are outcropping in lower areas of the peninsula originally interpreted as the upper unit of an ophiolitic pile collapsed by normal faulting (Schmidt-Effing, 1979). Azéma \& Tournon $(1980,1982)$ and Frisch et al. (1982) proposed an alternative interpretation, a nappe emplacement of the ultramafic massif onto a relative autochthonous unit made up of sedimentary and volcanic rock. The vergence of folds in the autochthonous unit indicates that the emplacement of Santa Elena nappe occurred from north to south relative to the autochthonous underneath unit (Azéma et al., 1985). Frisch et al. (1992), through fabrics studies indicate a south to west- southwest emplacement direction as well. The rudist reef limestone on top of the exhumed peridotites suggests that overthrusting occurred in the pre-late Campanian (Schmidt-Effing 1980). The nappe was emplaced after Cenomanian, the age of the youngest dated radiolarite in the underlying sediments (DeWever et al., 1985).

Geochemistry and petrological studies suggest mid-ocean rift, hotspot, and primitive island arc tectonic affinities (Appel et al., 1994; Meschede \& Frisch, 1994; Sinton et al., 1997; Beccaluva et al., 1999, Hauff et al., 2000). Hauff et al. (2000) and Gazel et al. (2006) presented a new integrated interpretation of the geochemistry and geotectonic significance of the Santa Elena Peninsula. It is divided in three units: 1) an overthrusted allochthonous unit composed by ultramafic and mafic rocks, the Santa Elena Nappe; 2) an autochthonous basaltic sedimentary suite, resting immediately below the overthrust, the Santa Rosa Accretionary Complex (Baumgartner \& Denyer, 2006); and 3) Murciélago Islands basalts.

Beccaluva et al. (1999) consider the basalts and gabbros at the Santa Rosa Accretionary Complex and the Santa Elena Nappe as typical N-MORB. Hauff et al. (2000) found two different geochemical affinities, first as oceanic island basalt (OIB), with strong light rare earth elements (LREE) enrichment in the Santa Rosa Accretionary Complex, Carrizal-Respingue section and Potrero Grande tectonic window, and second as primitive island arc basalts in the southeastern peninsula shoreline cliffs.

The serpentinized mantle peridotites of the Santa Elena Nappe have been correlated to serpentinized peridotites cropping out at both sides of the Costa Rican-Nicaraguan border (Fig. 1) and also, at the base of the Tonjibe 1 petroleum exploration drill hole (Fig. 1) (Astorga, 1992; Vargas \& Alfaro, 1992; Pizarro, 1993; Tournon et al., 1995). All of these ultramafic suites have been interpreted as part of an east-west suture zone between the southern oceanic-type crust of the Chorotega Block and the northern continental-type crust of the Chortis Block (Dengo, 1985; Tournon et al., 1995) in alignment with the Hess Escarpment (Holcombe et al., 1990). Serpentinized mantle peridotites have been 
found in Siuna Nicaragua (Venable, 1994; Rogers, 2003; Baumgartner et al., 2008) and in the DSDP (Deep Sea Drilling Project) sites 494 and 567 in the forearc of Central America (Geldmacher et al., 2008).

\section{Nicoya}

The rocks that form the Nicoya Complex were first described by Sapper $(1905,1937)$ and Romanes (1912a, b), and firstly considered Eocene in age by Sapper (1905, 1937). Sears (1919), Webber (1942) and Roberts (1944) made studies related to manganese deposits and they roughly described the surroundings lithologies. This lithologic assemblage was called Nicoya Complex by geologists of Union Oil Co. of California (first described in a internal draft in 1958 and then published in 1962), and included several sedimentary and igneous rocks their relationships were not completely established at that time. Dengo (1960, 1962a, b) and then Lloyd (1963) and Weyl (1965) established for the first time the oceanic crust origin of these lithologies, and interpreted them to represent a deep origin of the nowadays uplifted slice of the Pacific Ocean (Henningsen \& Weyl, 1967; Pichler \& Weyl, 1973). The first chemical analyses of magmatites of the Nicoya Complex were made by Dengo (1962a) and Weyl (1969), concluding oceanic tholeiites.

Henningsen \& Weyl (1967) previously suggested that the Nicoya Complex is probably obducted oceanic crust. Seely et al. (1974), GalliOlivier (1979), and Seely (1979) interpreted the Nicoya Complex as an accretionary prism characterized by thrust faults along a convergent and shortened plate margin. Other hypothesis suggests that the Nicoya Complex corresponds to an uplifted segment of the trench-slope break (Lundberg, 1982). Shipley et al. (1982) believe this complex as an "outer fore arc" portion that was accreted and uplifted due to the subdution of Cocos ridge. In similar way, De Boer (1979) interpreted the Nicoya Complex as emplaced by obduction, but with a few evidences that supported their interpretation. A much more imaginative model supported without any evidence or scientific data was presented by Nur
\& Ben-Avraham (1977); they interpreted the Nicoya Complex as a Precambriam piece of a lost continent called "Pacifica".

Schmidt-Effing $(1979,1980)$ utilized paleontology to produce one of the first stratigraphic subdivisions of the Nicoya Complex. He considered that the occurrences of radiolarites and silicic limestones were associated with the basaltic rocks. He also considered the concept of several igneous inclusions (xenoliths) within basalts (Fig. 3 ), and so, the xenoliths represent the maximum age of the lavas/intrusions, but not the age of the magmatism. He named the oldest complex (Jurassic-early Cretaceous) the Brasilito, and the successively younger complexes the Junquillal (Cenomanian), Murcielago (Campanian), Golfito (Maastrichtian); Garza (Maastrichtian); and Quepos (a mainland correlative of the Nicoya Complex at that time of Paleocene age). His complex subdivision, however, was not widely used.

De Boer (1979) also published a stratigraphy, which appears to commingle diverse lithologic units into two major divisions that are quite different from those of subsequent workers. His stratigraphy consisted of a "basement old complex" or the "Nicoya sensu stricto" including the Santa Elena peridotites, pillow lavas (the Coyote-Junquillal unit), and the pelagic radiolarites (Sardinal Formation). His "basement young complex" contained a plutonic portion (Bahía Culebra) and pillow basalts, and volcanic breccias (Montezuma type).

The majority of the authors assumed that the age of the radiolarites were closer to the age of magmatism, putting away the clear magmatic and tectonic contacts or sub-estimated their role. Thus, in general, those authors have subdivided the Nicoya Peninsula igneous rocks into two or three general units, although no contact between those units was well defined. The dominantly plutonic unit, was called the Lower Nicoya Complex (Wildberg et al., 1981; Gursky et al., 1984; Wildberg, 1984), the Matapalo unit (Kuijpers, 1980), and the Coco unit (Sick, 1988; Frisch et al., 1992). The dominantly volcanic-sedimentary part of the Nicoya Complex was called the Upper Nicoya Complex (Wildberg et al., 1981; Gursky et al.,. 1982, 1984), the Esperanza unit (Kuijpers, 1980), and the Tambor unit (Sick, 1989, Frisch et al., 1992) (Fig. 3). 
Wildberg (1984) made the first systematic analysis of igneous geochemistry in the Nicoya Peninsula. He concluded that both MORB and primitive island arc rocks were present in the Peninsula. Meschede \& Frisch (1994) published one of the major databases of geochemical analyses from various basaltic units along the Costa Rican Pacific coast. They reported mid-ocean ridge basalts, island arc tholeiites, within-plate tholeiites and alkali basalts. Gursky et al. (1982) and Wildberg (1984) based in "Pearce diagrams" (eg. Fig. 4) assumed that the Lower Nicoya was formed in a Pacific spreading ridge and represents oceanic crust or mid-ocean ridge basalts (MORB), usually with slight affinities to island-arc tholeiites and of within basaltic tholeiites (WPT) of probably Lower Jurassic age. The Upper Nicoya Complex instead was described as composed of basaltic rocks of different affinity, corresponding to an island arc evolving on oceanic crust and faulted by horst and graben tectonics (Wildberg et al., 1981; Wildberg, 1984; Frisch et al., 1992). Those studies based on chemical data proposed that the ophiolite bodies are the result of a complex evolutionary history from ocean floor overlaid by a primitive island-arc stage and a major
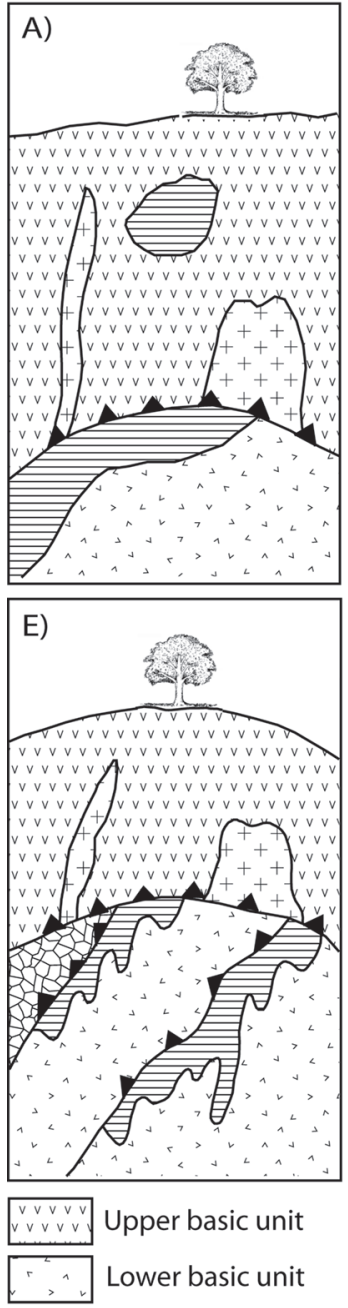
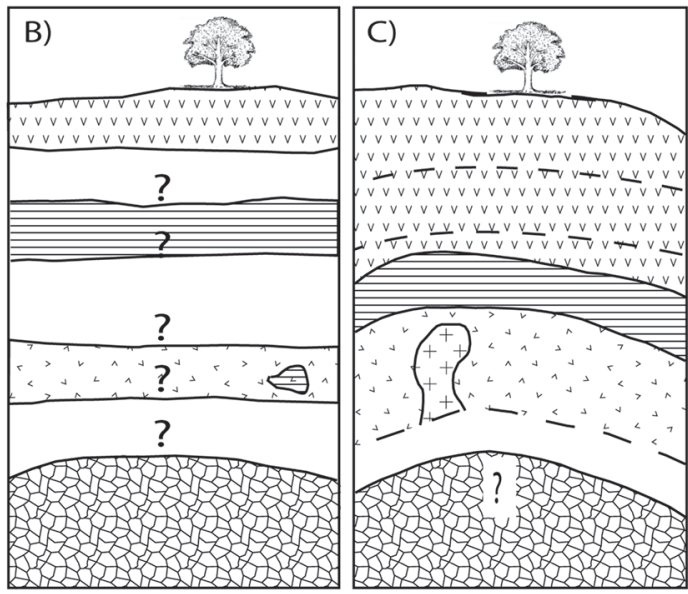

F)

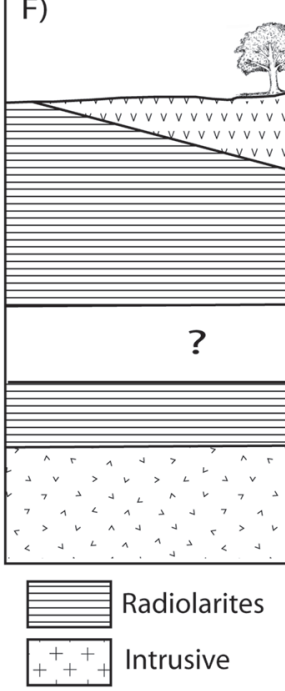

\section{G)}
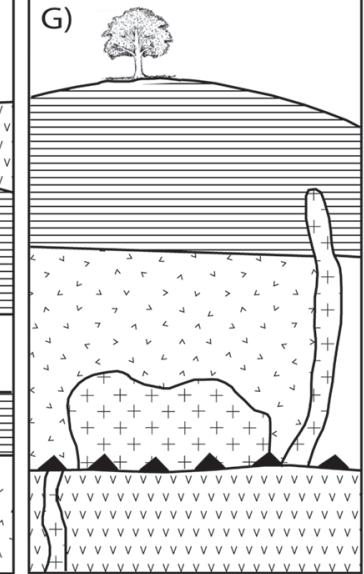

Peridotite/Serpentinite

CLIP pulses
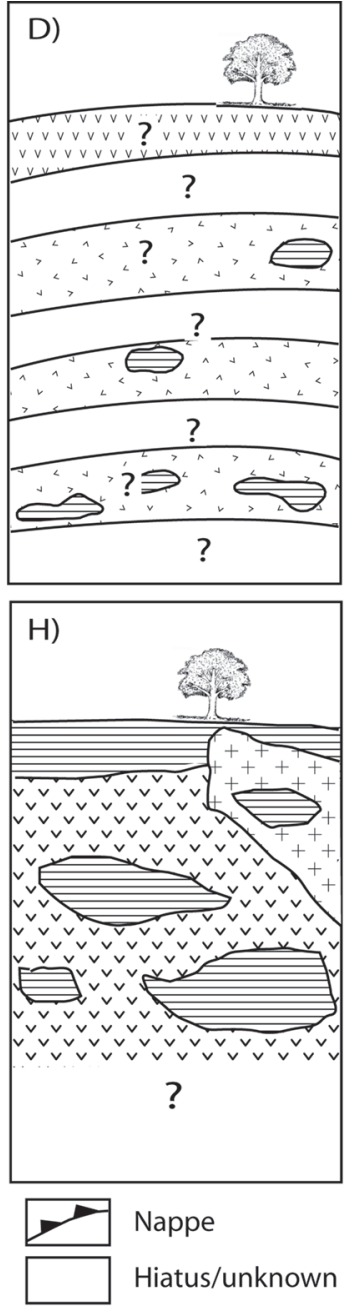

Fig.3: Different structural and stratigraphic models of the Nicoya Complex in the Nicoya Peninsula. a) Kuipers (1979, 1980); b) De Boer (1979); c) Grusky and co-workers (1982-94), d) Schmidt-Effing (1979, 1980), e) Baumgartner (1984, 1987); f) Frisch et al. (1982); g) Azema et al. (1985); and h) Denyer \& Baumgartner (2006). 
A)

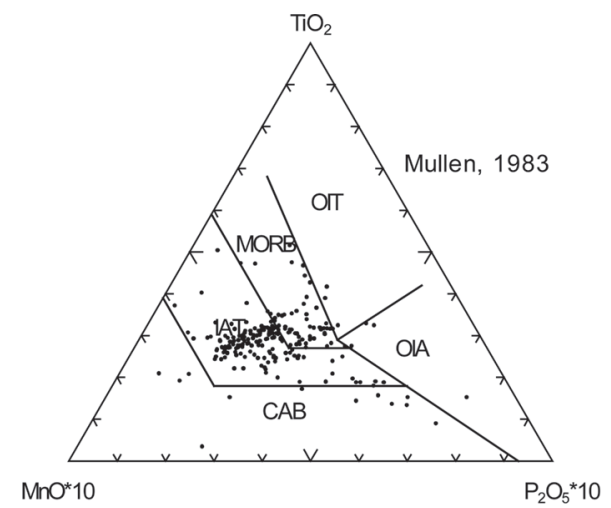

Pearce and Norry, 1979

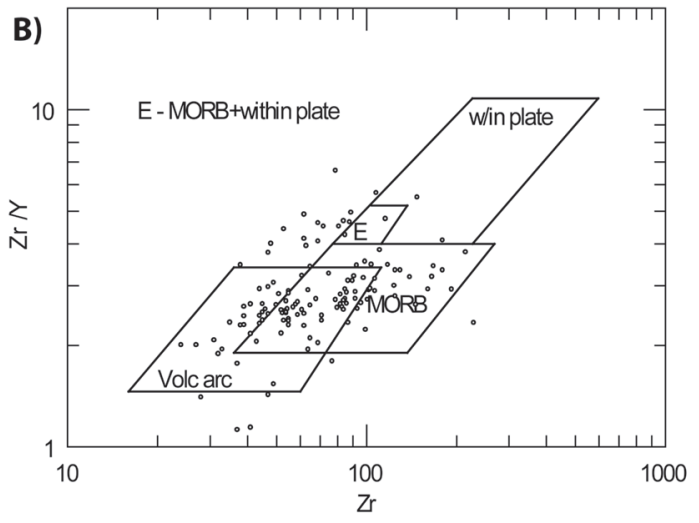

C)

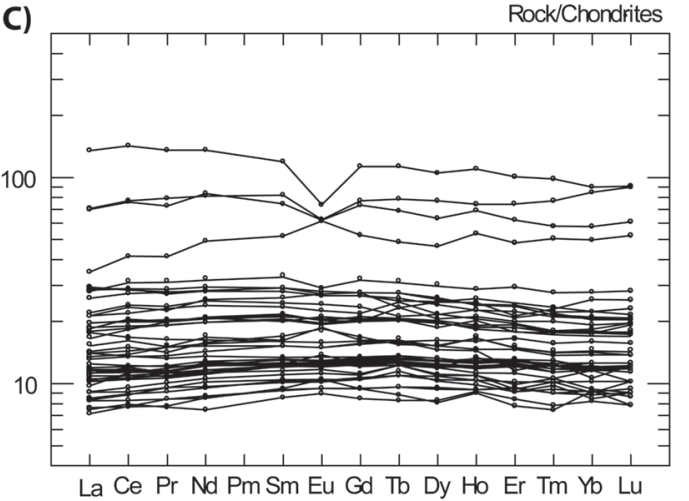

Fig.4: Comparison of old and recent petrogenetic diagrams as examples.

intra-plate event (correlated with the "sill event" of the Caribbean; Donnelly et al., 1973, 1990).

Based on observations, Kuijpers (1980) and Tournon \& Azéma (1980), Bourgois et al. (1984) presented a tectonic model with three nappes in the Nicoya peninsula (Fig. 3). Both, the lower Esperanza and the higher Matapalo Nappe contain basaltic rocks and radiolarian chert ("volcanicsedimentary unit" of Tournon, 1984). These authors interpreted the Santa Elena Nappe as the tectonically highest unit, mainly consisting of ultramafic rocks. They also, interpreted the Santa Elena and Matapalo Nappe essentially made up of rocks from the Lower Nicoya Complex, and the Esperanza Nappe containing the sequence of the Upper Nicoya Complex.

Only scarce paleomagnetic data from Costa Rica and Panama have been published. De Boer (1979) presented data for 87 samples from basaltic rocks of the Nicoya peninsula without information on the number of sample sites or locations. He inferred gradual clockwise rotation from an east-west-trending aeromagnetic pattern in the northern Nicoya Peninsula, although the paleomagnetic data do not support such an interpretation. Gose (1983) carried out a paleomagnetic study on post-Campanian sedimentary rocks. His results, obtained from 324 samples of 14 sites, reveal the formation of these rocks in an equatorial position and post-Eocene northward translation with no rotation. Sick (1989) and Frisch et al. (1992) concluded that the ophiolites formed in a position which is similar to the present one relative to South America. Crosscutting dikes are paleomagnetically included in the neoautochthonous sequence by Frisch et al. (1992). Case et al. (1984) and Howell et al. (1985) summarized the Central American ophiolites as the Nicoya terrane assuming a place of origin on the Farrallon plate in the Jurassic.

The radiolarites have ages of Early Jurassic (Callovian) to Late Cretaceous (early Santonian) (Galli-Olivier, 1979; Bourgois et al., 1984; Baumgartner et al., 1984). However, because they occur as inclusions (mega- to mesoxenoliths) within the igneous rocks throughout the peninsula, the fossil ages provide only a maximum crystallization age of the igneous rocks. The late Campanian ( 75-70 Ma) Sabana Grande sediments conformably overlie the igneous rocks (Bourgois et al., 1984), placing a minimum age on the eruption and crystallization of the magmas. This formation corresponds to a deep-water assemblage of a sedimentary basalt/radiolarian breccias overlain by thin siliceous mudstones grading into limestone (Bourgois et al., 1984). 
$\mathrm{K} / \mathrm{Ar}$ radiometric ages of the Nicoya Peninsula rocks have not been useful in constraining their magmatic history. Alvarado et al. (1992) compiled from the literature ${ }^{40} \mathrm{Ar} /{ }^{39} \mathrm{Ar}$ ages that range from 30 to $73 \mathrm{Ma}$, reflecting the effects of alteration and ${ }^{40} \mathrm{Ar}$ loss and not the actual time span of volcanism. Recent geochemical data and ${ }^{40} \mathrm{Ar} /{ }^{39} \mathrm{Ar}$ dating by Sinton et al. (1997), Hauff et al. (1997), Hauff et al. (2000) and Hoernle et al. (2004), however, have largely confirmed that the Nicoya Peninsula constitute a portion of the Caribbean Plateau. The Late Cretaceous ${ }^{40} \mathrm{Ar} /{ }^{39} \mathrm{Ar}$ data are in contradiction to previous radiolarian biochronology of the northern Nicoya Peninsula (cf. Baumgartner, 1984a; 1987; Baumgartner et al. 1995) that yields Middle Jurassic to Late Cretaceous ages, indicating that in effect the radiolarites were megaxenoliths. However, it was not until the work of Denyer \& Baumgartner (2006) which explained the radiolarites as large disrupted pieces of the original basaltic basement by a multi-magmatic process (Fig. 3), producing enormous blocks of radiolarites of different ages.

\section{Tortugal}

Alvarado et al. (1997) and Alvarado \& Denyer (1998) published detailed petrographic, petrological, stratigrafic and structural data on a relative small area of ca. $50 \mathrm{~km}^{2}$, which contribute significantly to a new view of the origin of part of the ophiolitic complexes. Their work focused on the northern part of the Nicoya Gulf, where a large ultramafic volcanic unit was for the first time well identified within the Nicoya Complex. These rich olivine-phyric (25-50\%) volcanic rocks are restricted to a $\mathrm{N} 60^{\circ} \mathrm{W}$ trend, $14 \mathrm{~km}$ long and up to $1.5 \mathrm{~km}$ wide, located between Tortugal and Pueblo Nuevo towns (Fig. 1).

Romanes (1912b) firstly report a limburgite. Latter, Aguilar (1977) also found isolated basalts (60\% modal olivine) near Pueblo Nuevo town, which Galli (1979) interpreted as harzburgite. Tournon (1984) reported for the same area an isolated block of picrite instead, and Calero (1987) reported in the Tortugal area a similar ultramafic rock but classified it as lamprophyre (monchiquite). These rocks were mapped, dated and interpreted as picrites with geochemical affinity to komatiites (Alvarado \& Denyer, 1998).

The ultramafic unit is intruded by thin (a few meters to less than $2 \mathrm{~cm}$ wide) trachybasalts and surrounded and overlain by massive basalts, trachybasalts and basaltic trachy-andesite flows and breccias. Subvolcanic rocks (diabase) are of similar geochemical compositions. The geochemistry of these basaltic rocks, follows an alkaline tendency, in general they are not similar to the volcanic rocks from the typical Nicoya Complex (Alvarado \& Denyer, 1998).

\section{Herradura}

The Herradura Block is a large area, bigger than $1000 \mathrm{~km}^{2}$, with altitudes up to $1500 \mathrm{~m}$. The Herradura complex is made up by two major units. The lower one is a lateral equivalent to Nicoya Complex and the upper one is known as the Tulín Formation (Arias, 2003). The Nicoya Complex outcrops in the south-eastern edge of the Herradura Block, geochemically consistent with the Caribbean Ocean Plateau (Hauff et al., 2000; Arias, 2003). Two ${ }^{40} \mathrm{Ar} /{ }^{39} \mathrm{Ar}$ ages have been reported as $83.2 \pm 1.8 \mathrm{Ma}$ (Sinton et al., 1997) and $86.0 \pm 2.0 \mathrm{Ma}$ (Hauff et al., 2000). The Tulín Formation was defined by Malavassi (1967) and then by MIEM (1982). It was redefined by Arias (2003) as a Maastrichtian to Lower Eocene basaltic sequence, based on micropaleontological data of interbedded sediments. Tulín overlies the Nicoya Complex, which is dominated by vesicular pillow basalts with microdoleritic texture.

\section{Quepos}

Quepos was classified as a mélange of Paleocene age by Schmidt-Effing (1980). Vesiclerich basaltic rocks from Quepos display typical characteristics of intraplate tholeiites, and do not support their interpretation by Baumgartner et al. (1984) as an island-arc fragment of Eocene to Miocene age. In fact, Meschede \& Frisch (1991) interpreted this exotic block as a seamount accreted to the Central American during the Lower to Middle Tertiary. 
The volcanic rocks at Quepos provide clear evidence of the emergence of a submarine volcanic edifice above sea level and the formation of an ocean island (Hauff et al., 1997). Radiometric (Sinton et al., 1997; Hauff et al., 2000) and biostratigraphic ages (Azema et al., 1979; Baumgartner et al., 1984) suggest that the seamount/ocean island volcano was active between 59 and $65 \mathrm{Ma}$.

\section{Osa-Burica}

The Osa-Burica region includes the area formed by the Osa and Burica peninsula including the inland Golfito area and Caño Island subject of only limited studies. The first published geological observations were made by Dengo (1962a) who drew a schematic cross-section through southwest Costa Rica in which he showed the Osa Peninsula and Golfito as part of the outer arc of the Southern Central America Orogen, which consists of undifferentiated Nicoya Complex (including basalt, gabbro and limestone) covered by Upper Cretaceous and Tertiary sediments. Based on micropaleontological dating of foraminifera in limestones associated with the basalts, Henningsen (1966) assigned a Campanian age to the Basal (e.g. Nicoya) Complex of the OsaGolfito region and suggested that its sediments were derived from "volcanic islands" in the Pacific Ocean. Based on the foraminifera content of samples collected along the south coast of the Osa Peninsula, Azéma et al. (1981, 1982) demonstrated a Paleocene age for the Nicoya Complex in this area, and Azéma et al. (1983) similarly identified volcano-sedimentary rocks of Middle Eocene age in the vicinity of Drake Bay on the west coast of the peninsula. Lew (1983a, b) mapped and described a sequence of pelagic cherts and limestones of the Late Mesozoic to Early Tertiary age along the southern coast of the peninsula, which he inferred to be deposited on oceanic crust and were intruded and covered by Lower Eocene basalts.

Late Campanian through middle Maastrichian limestones in the Golfito area and interbedded sediments of similar age of Burica suggest that the formation of the igneous rocks started before 74 Ma (Di Marco, 1994). K/Ar ages of basaltic rocks give a mean value of Late Cretaceous (Berrangé et al., 1989), in agreement with a few ${ }^{40} \mathrm{Ar} /{ }^{39} \mathrm{Ar}$ results of 70-74 Ma (Hauff et al., 2000).

The geologic conception of this area has changed considerably through time. The earlier authors (e.g. Berrangé et al., 1989) conceptually mapped all the Osa peninsula and Caño island as belonging to Nicoya Complex. Later, Di Marco (1994) restricted the igneous sequence to the inner part of Osa peninsula, and most of this peninsula corresponds to the Osa-Caño Accretionary Complex (Fig. 1). Finally, the oceanic assemblage was divided into five tectonic units (Di Marco, 1994; Di Marco et al., 1995; Buchs \& Stucki, 2001; Buchs \& Baumgartner, 2003), with different origins. The outer Osa peninsula and the Caño Island have been mapped as igneous assemblages, but actually are composed by sedimentary mega-breccias (Di Marco et al., 1995) that are now named the Osa-Caño Accretionary prism. The Golfito Terrane (Upper Cretaceous) and the Burica Terrane (Upper Cretaceous-Paleogene) represent segments of oceanic plateau assemblages. The Rincón Block is an Upper-Cretaceous-Eocene seamount and oceanic plateau sequences (Hauff et al., 2000; Buchs \& Baumgartner, 2003).

The Osa-Caño Accretionary Complex was also referred as the Osa Mélange by Vannucchi et al. (2006) and Buchs \& Baumgartner (2007) and described as a variably disrupted unit described as well as a block-in-matrix fabric mélange. Baumgartner (1986) documented the presence of a similar mélange in the Caño Island.

Geochemical analyses (Berrangé \& Thorpe, 1988; Hauff et al., 2000) from different blocks of the mélange show plateau signature and in fewer proportion depleted LREE patterns, and OIB affinities. This variability is congruent with an accretionary prism.

\section{DISCUSSION}

The proliferation of research in the Costa Rican ophiolites (particularly in the Nicoya Complex s.s.) has led to considerable confusion about the stratigraphy of this complex, and its relation to the other oceanic complexes. Geologic 
sketch maps published by several authors show only a crude correspondence to each other, reflecting the commonly poor outcrop and lithologic complexity of these units.

The historical significance of the geological ideas about the ophiolites in Costa Rica is full of paradigmatic ideas (models-on-fashion from the literature) that have confused the whole geological panorama. The history of the Costa Rican ophiolitic complexes could be divided in four major stages of advances, confusing and clarified ideas, and most of them in the framework of the paradigms ("state of the art") or fashion of the historical glance.

\section{Discovery and first petrography descriptions (1904-1957)}

This period corresponds to the first recognition of the mafic and ultramafic igneous complexes (Sapper, 1905, Romanes, 1912a, b; Sears, 1919; Webber, 1942; Harrison, 1953), first regional maps (Sapper, 1905, 1937), and petrographic descriptions. Roberts \& Irving (1957) were probably the first ones to recognize ellipsoidal basalts, now widely known as pillow lavas. All this period is developed almost at the margin of the recent continental drifting and plate tectonic model, but under the precept of the association of ophiolites (serpentine, gabbro, diabase, spilite, and related rocks), and interpreted the radiolarites as deep-sea conditions (Steinmann, 1905, 1927).

\section{Recognized as an ophiolite suite in the frame- work of the plate tectonics (1958-1978)}

This stage is characterized by the seminal work of Gabriel Dengo (Fig. 5) and by the first geochemical analyses in the framework of the recent plate tectonics. The development of the plate tectonic theory and the marine geology in the 60's and 70's has led to enormous changes in the geologic ideas, and new solutions to the previous petro-tectonic misunderstandings.

Dengo (1962a, b) and other colleges of the oil company firstly interpreted the basement as an assemblage of different rocks with intricate structural relations, deserving the category of "complex", years before that this term was adopted as part of the formal stratigraphic nomenclature and as a name for the Franciscan Complex of North America (Galli-Oliver, 1979). Henningsen \& Weyl (1967) suggested that the Nicoya Complex probably represents obducted oceanic crust and Seely et al. (1974) interpreted it as an accretionary prism.

Using the geochemical data as a tool and the plate tectonics as a model, the ophiolite complexes lined up along the Pacific coast of Costa Rica, Panama, and Colombia were studied under this framework. They appear to have a complex history from Jurassic through Paleocene time and they probably derived from an originally coherent body (Pichler et al., 1974; Goossens et al., 1977). The increased geochemical and geological data confirmed at that time the correlation of similar rocks from the northwestern South America and the South part of Central America. Although the geochemical data supported an ocean-floor tholeiite association, however, the higher concentrations of $\mathrm{K}_{2} \mathrm{O}$ and $\mathrm{Sr}$, and the relative prominence of andesites are features that were suspicious for a "youthful" island arc (Goossens et al., 1977).

The Escuela Centroamericana de Geología, University of Costa Rica, since its earliest days (1977) started mapping in detail the Nicoya Peninsula, which represents a solid base for the future research on the oceanic complexes.

\section{The nappe versus normal emplaced model, petrologic studies and its geotectonic interpre- tations (1979-1994)}

The publication of the textbook of Coleman (1977), the beginning of mobilistic models (tectonic nappes, obduction, terranes, accretion) the use of a considerable amount of geochemical analyses (including $\mathrm{Sr}$ isotopes and tectono-magmatic diagrams) of igneous rocks (Fig, 4), together with sedimentology of the radiolarites, and extensive mapping dominated this stage of scientific research.

The scientists recognized that the so called "Steinmann's trinity" (Hess, 1938, 1955) that means uplifted segments of ancient oceanic crust (ophiolite: peridotite/serpentine-basalts-radiolarites), was related to oceanic crust, a typical four 


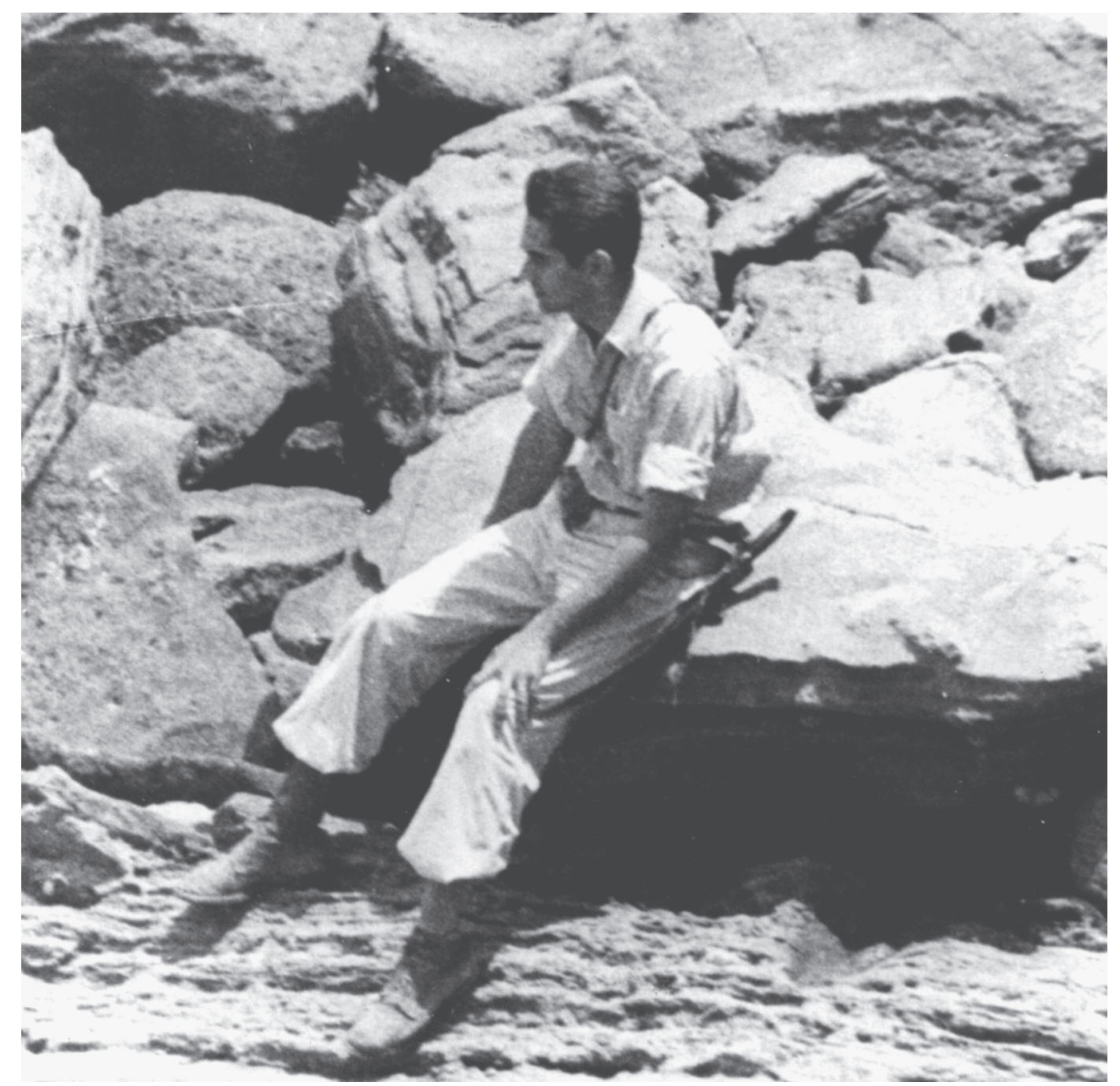

Fig. 5: Historical photograph of Gabriel Dengo, who wrote the seminal papers between 1960 and 1985 about the Nicoya Complex and other occurrences along Costa Rica, Guatemala and South America. This photograph is part of the historical collection of the Escuela Centroamericana de Geología, it was given by G.E. Alvarado. Unknown photographer.

layer succession model (i.e. Brown \& Mussett, 1981), and their allochthony significance from an environment distinctly different from where they occur today (Coleman, 1977). Galli-Olivier (1979) was one of the first who used in Costa Rica the correlation between the oceanic crust and the ophiolitic outcrops: peridotite (level 3 or level 4 sensu Brown \& Mussett, 1981), basalts (level 2) and pelagic sediments (level 1). He interpreted the Nicoya Complex as an accretionary prism and the sedimentary covertures as miogeosyclinal, based on Karig \& Sharman (1975). Galli-Olivier (1979) and Seely (1979) interpreted the Nicoya Complex as an accretionary prism characterized by thrust faults along a convergent and shortened plate margin. In similar way, De Boer (1979) interpreted that the Nicoya Complex was emplaced by obduction.

Schmidt-Effing $(1979,1980)$ found numerous occurrences of radiolarites and siliceous-limestones associated with the basaltic rocks, but mostly as inclusions (xenoliths). Even though 
several scientists described tectonic and/or magmatic contacts between the radiolarites and igneous rocks, the majority of these scientists at that time assumed that the age of the radiolarites was close to the age of magmatism (i.e. Kuipers, 1980; Azéma et al., 1984; Gurshy \& Gursky, 1988), and they paid less attentions to the relevant geological observation of Schmidt-Effing. The main reason was funded on the previously mentioned "Steinmann's trinity", in which a radiolarite is deposited on a basaltic basement, and therefore, the radiolarites must be younger than the magmatic rocks.

Based on that, the Nicoya Complex, cropping out in the Nicoya Peninsula, was divided in several major units, depending of the researchers:

a) The Brasilito, Junquillal and Murciélago Sub-Complexes (Schmidt-Effing, 1979, 1980), the Matapalo unit (Kuijpers, 1979, 1980), the Lower Nicoya Complex (Wilberg et al., 1981; Gursky et al., 1984), or and the Coco unit (Sick, 1988; Frisch et al., 1992).

b) The most recent unit was named in Garza Sub-Complex (Schmidt-Effing, 1979, 1980), Esperanza unit (Kuijpers, 1979, 1980), Upper Nicoya Complex (Wildberg et al., 1981; Gursky et al., 1984), or Tambor unit (Sick, 1989, Frisch et al., 1992).

There are several conceptual differences among these authors. For some research groups the major responsible mechanisms of emplacement is the tectonic overlapping by large nappes (Kuipers, 1979, 1980; Baumgartner, 1984, 1987; Bourgoeis et al. 1984; Azema et al., 1985). However, for others there is a normal stratigraphic development by different volcanic successions (Wilberg et al., 1981; Gursky et al., 1981).

Within the "nappe-in-favor group", there are great contradictions. a) Kuijpers $(1979,1980)$ believed that younger rocks (Esperanza unit) overthurst the older ones (Matapalo), against the common model of a nappe. b) For other authors, the older rocks overthrusted the younger ones. Thus, for Bourgois et al. (1984), Azema et al. (1985), and Baumgartner $(1984,1987)$, the Esperanza unit is overthrusted by Matapalo, an older unit. In the same way, the Santa Elena nappe in the Santa Elena Peninsula is the oldest overthrusting unit.
Using tectono-magmatic diagrams (e.g, Fig. 5) and $\mathrm{Sr}$ isotopic analyses, Wildberg (1982) concluded the Lower Nicoya Complex showed a typically ophiolitic association that represents oceanic crust of probably Upper Jurassic age. In contrast, the Upper Nicoya Complex consists of two geochemically distinct subunits: and oceanic series and an island arc series (low potassium tholeiites and calcalkaline trend plutonites). Meschede \& Frisch (1994) published one of the major petrochemical databases from the Costa Rican ophiolitic units at that time.

Anyway, none of these terms is consistently defined and none has a type section and they are not all strictly stratigraphic, because "Matapalo" and "Esperanza" are also used in a structural sense. "Matapalo" as defined includes the radiolarites, which De Boer (1979) called Sardinal Formation, Sick (1989) as Sardinal unit, and Gursky et al. (1984) called the Punta Conchal Formation. In general, the authors after Frisch et al. (1992) did not put their new data in stratigraphical detailed columns, but these further authors used other methodologies, more techonologically supported.

In addition, there are no observed depositional contacts between the radiolarian chert and the igneous rocks. This observation as well as considerable differences in the interpretation of the stratigraphy and origin of the rocks led Donnelly (1994) to suggest that the Nicoya Peninsula igneous rocks may be a single unit.

Contemporaneously, the Nicoya Complex was interpreted as an uplifted segment of the trenchslope break (Lundberg, 1982), or as an "outer fore arc" portion that was accreted and uplifted due to the subdution of Cocos ridge (Shipley et al., 1982), or as the product of an uplift of Caribbean oceanic plateau crust (Duncan \& Hargraves, 1984; Donnelly et al.,1990)

Finally, an interesting conclusion was presented by Flüeh (1983) based on the geographical distribution of the Basic Igneous Complex in the northern part of South America, he considered that probably the aseismic ridges were formed on the Farallón Plate, overriding the Galápagos hot spot, which is similar to the formation of the present Cocos and Carnegie Ridges. It implies that the Galápagos hot spot had been active since the 
Jurassic. Therefore, the different oceanic complexes represent accretion of the Galápagos paleohotspot tracks. Denyer \& Arias (1993) did a similar conclusion.

\section{The modern isotope petrology and volcanol- ogy (1995 to present)}

As we commented above, most of the previous works are in favor of a multistage geodynamic evolution, beginning with oceanic crust formation at a mid-ocean ridge, followed by intraplate, island arc, and back arc basin volcanism. The controversy for almost two decades mainly results from the lack of reliable data on the age and geochemistry of the igneous complexes. In most of the papers, it was assumed that to date the magmatism must be primarily a sedimentary contact based in the "Steinmann's trinity", even though most of the contacts between sedimentary (radiolarites) and igneous rocks are predominantly tectonic or intrusive.

Until 1994, the radiometric dating studies were conducted on complete rocks using the K/Ar analyses methods, which application is problematic for low-K altered rocks, affected also by a low-grade metamorphism (see Alvarado et al., 1992 and Appel et al., 1994 for a summary). Since 1995, different joint German-Costa Rican-USA groups, using new petrological studies in fresh rocks (e.g., basaltic glasses), $\mathrm{Pb}, \mathrm{Nb}, \mathrm{Sr}$, $\mathrm{Hf}$ isotopes, major, trace, and complete rare earth elements, ${ }^{40} \mathrm{Ar} /{ }^{39} \mathrm{Ar}$ dating and volcanological criteria provided new and challenging conclusions (e.g. Hauff et al., 1997, 2000; Sinton et al., 1997; Alvarado et al., 1997; Alvarado \& Denyer, 1998; Arias, 2003; Hoernle et al., 2002, 2004). These investigations showed that most of the basic igenous complexes were formed between 142 and 40 Ma from a plume-type mantle source, possibly the Galápagos hot spot. According to these authors, the Nicoya and lower part of Herradura complexes mark the westernmost edge of the Caribbean Large Igneous Province (CLIP), while the younger Herradura, Quepos terrane represents an accreted seamount/ocean island complex of the early Galápagos hotspot track. However, the age and origin of the other igneous complexes (i.e. Osa-Golfito, Burica) are still poorly constrained.
The "Steinmann's trinity" concept and its normal stratigraphy do not match in the majority of the cases of the Costa Rican ophiolites. In fact, it was, perhaps, one of the more difficult obstacles to began to understand the stratigraphic and tectonic relationships of the Costa Rican oceanic complexes. It was not only until the use of ${ }^{40} \mathrm{Ar} /{ }^{39} \mathrm{Ar}$ isotopic ages that it was clear that there are inconsistencies between the basaltic event ages and radiolarian dates, aspect that was recognized by Hauff et al. (1997) and Sinton et al. (1997), but no explanation was given. Both group of authors concluded that the radiolarites ages do not represent the formation age of the igneous neighbor rocks. Thus, Denyer \& Baumgartner (2006) present a new model, in which multiple magmatic events that occurred during different pulses of the CLIP, detached and disrupted the radiolarites (164-84 $\mathrm{Ma}$ ) from the original basaltic basement.

Currently, there is a general agreement to use the term of Nicoya Complex restricted to rocks older than Lower Campanian-Santonian, and most of the previous works have largely confirmed the view of these rocks as a portion of the CLIP or as a plateau, geochemically similar to the Galápagos hotspot.

\section{CONCLUSIONS}

The oceanic crust outcrops are one of the most important records for the understanding of the origin and geotectonic history of the Middle American convergent margin. The oceanic assemblages cropping out in the Pacific of Costa Rica have been relatively well studied, especially in the northwestern part of Costa Rica. Micropaleontological, geochemical, and petrological techniques have been applied to these units in the 60's of the last century. However, the history of oceanic assemblages of the pacific margin of southern Central America is still very incomplete. It seems that they consist of portions of material already subducted during Mesozoic and Cenozoic. The presence of enormous volumes of oceanic related rocks means that the accretion process has been very important in the emplacement of these oceanic complexes. 
Concerning to the petrological, geochemical, and isotopic studies, the comparison of the different authors is very difficult because of the great progress and rapid changes in geochemical analyses technology (see Table 1).

Several authors have considered an ophiolitic model, mostly in relation to the Nicoya Complex outcropping in the Nicoya Peninsula together with the ultramafics of Santa Elena Peninsula (e.g. De Boer, 1979; Kuijpers, 1980; Berrange \& Thorpe, 1989; Beccaaluva et al., 1999). Other authors (e.g. Berrangé et al., 1988) extended the name of Nicoya Complex to refer to other oceanic occurrences of the Pacific side of Costa Rica, despite of their different ages and origin. However, there is a general consensus inthe use of the term Nicoya Complex restricted to the sequences older than Lower CampanianSantonian, and restricted to Nicoya Peninsula and the base of the Herradura block. However, there are several other oceanic basic and ultrabasic igneous complexes of different ages, origin and mode of emplacement that require further work.

Most of the igneous Mesozoic-Cenozoic assemblages have a geochemical signature similar to the Galápagos mantle plume, as suggested by the last results (Sinton et al., 1997; Beccaluva et al., 1999; Hauff et al., 2000; Hoernle et al., 2002; Hoernle et al., 2004). If so, the Galápagos hotspot must have been during the Caribbean Basalt Event larger than today or there were several thermal spots occurring at the same time and distributed widely enough, to thicken the crust of the newborn Caribbean plate. The interpretation of several pulses of this thermal source happening during $140 \mathrm{Ma}$ (Hoernle et. al., 2002; Hoernle et al., 2004) is also difficult to imagine in the actual geotectonic framework. Therefore, Denyer et al. (2006) consider premature the presumption that all oceanic assemblages came from the same source. The geotectonic history of this area could be more complicated, and there could be several plateaus with similar signatures piled up along the eastern side of the active margin.

The serpentinized mantle peridotites of Santa Elena Peninsula, Río San Juan, and Tonjibe drill hole are one of the most intriguing pieces of the southern Central America oceanic occurrences. Only the Santa Elena Peninsula has been studied in detail. They could easily be interpreted as suture zones, but the genetic relationships are not clear and the trends are not known, although an E-W suture zone have been suggested between Santa Elena Peninsula and Río San Juan occurrences. More research and mapping must be done in order to understand the significance of all these occurrences in the oceanic plateau model. In addition, the mechanism of emplacement of the seamounts and the volcanic edifices is not well understood. Tulín Formation and Quepos Block appear to be mega-structures reaching today altitudes up to 1500 meters above sea level.

Detailed mapping is still a very useful tool to understand the original oceanic structure and the emplacement form. For example, Denyer \& Arias (1991) demonstrated from their geological maps that the radiolarian occurrences are not continuous (in contrast to Gursky and co-wokers), and are mostly dismembered radiolarite sequences ranging from Callovian to Santonian (164-84 Ma; Schmidt-Effing, 1979; Baumgartner, 1984, 1987). Di Marco et al. (1995) by detailed mapping of Osa and Golfito, demonstrated not only the existence of terranes, but also the presence of a large mélange area, not previously recognized. In the same way, the detailed mapping of the Tortugal area (only $50 \mathrm{~km}^{2}$ ) by Alvarado et al. (1997) and Alvarado \& Denyer (1998), contributed significantly to a new view of the origin of part of the ophiolitic complexes, where for the first time a $14 \mathrm{~km}$ long and up to $1.5 \mathrm{~km}$ wide ultramafic volcanic rocks was identified. Therefore, we are in favor that more detailed mapping and volcanologic stratigraphic columns are necessary to make a complete picture of the oceanic basic complexes.

The terranes that have been identified by $\mathrm{Di}$ Marco (1994), following by the works of Di Marco et al. (1995); Buchs \& Stucki (2001), Buchs \& Baumgartner, (2003) represent a first step in the study of the different terranes that have been piled to form the pacific ophiolitic occurrences. We consider that the further research will confirm the existence of more exotic terranes. It seems to be obvious from stratigraphic differences in the Cretaceous sedimentary sequences, which are incompatible with a single place of formation. For 
example, looking the magnetic map of Ranero et al. (2007) it is possible to recognize two large blocks in the Nicoya Peninsula. Previously, De Boer (1979) proposed the Belén Fracture Zone to divide both blocks.

All the different oceanic occurrences have so strong grade of tectonism, sinsedimentary deformation and intrusion that could be visualized as sedimentary, tectonic and magmatic megabreccias or true mélanges.

Finally, a similar historical evolution in the ideas of the ophiolites in the Greater Antilles (Iturralde-Vinent, 1996; Iturralde-Vinent \& MacPhee, 1999), South America (Goossens et al., 1977), and Central America (Hoernle \& Hauff, 2007, and references therein) is more than a coincidence. A multidisciplinary study of the chrono- and bio-stratigraphic relations, together with petrology, geochemical and micropaleontology approach could be appropriate to correlate and understand the Caribbean region. This would lead to understand the evolution of the Americas, and all these elements would provide a solid basis for a more realistic plate tectonic reconstruction, stratigraphical correlations, and geologic history.

\section{ACKNOWLEDGMENTS}

This research was funded by the Vicerrectoría de Investigación, Universidad de Costa Rica, projects 830-A5-047 and 830-A5-162. We thank Michael Carr, Lina Patino, Ian Saginor and Dana Foley for reviewing previous versions of this article. We acknowledge the final revisions and help by O. Arias, O. Breedy and S. Kussmaul.

\section{REFERENCES}

AGUILAR, A.T., 1977: Geología del área de las Lomas Monte Potrero y alrededores, cantón de Abangares, provincia de Guanacaste, Costa Rica.- 21 págs. Univ. Costa Rica, San José [Inf. Campaña Geol.].

ALVARADO, G.E., KUSSMAUL, S., CHIESA, S., GILLOT, P.-Y., APPEL, H., WÖRNER,
G. \& RUNDLE, C., 1992: Resumen cronoestratigráfico de las rocas ígneas de Costa Rica basado en dataciones radiométricas.- J. South Amer. Earth Sci. 6(3): 151-168.

ALVARADO, G. \& DENYER, P., 1998: Implications for the Caribbean region of the high-Mg volcanic rocks in the Costa Rican ophiolitic complexes: The case of the Tortugal komatiitic-like suite.- Zentralblatt für Geologie und Paläontologie, 1977(3-6): 409-429.

ALVARADO, G., DENYER, P. \& SINTON, C., 1997: The 89 Ma Tortugal komatiitic suite, Costa Rica: implications for a common geological origin of the Caribbean and Eastern Pacific region from a mantle plume.- Geology, 25(5): 439-442.

ALVARADO, G., DENYER, P. \& SINTON, C., 1997: The 89 Ma Tortugal komatiitic suite, Costa Rica: implications for a common geological origin of the Caribbean and Eastern Pacific region from a mantle plume.- Geology, 25(5): 439-442.

ANONYMOUS, 1972: Penrose field conference on ophiolites.- Geotimes, 17: 24-25.

ARIAS, O., 2000: Geología y petrología magmática del bloque Herradura (Cretácico Superior-Eoceno), Costa Rica.- 186 págs. Univ. Lausanne, Suisse [Tesis Ph.D].

ARIAS, O., 2003: Redefinición de la Formación Tulín (Mastrichtiano-Eoceno Inferior) del pacífico central de Costa Rica.- Rev. Geol. Amér. Central, 28: 47-68.

ASTORGA, A., 1992: Descubrimiento de corteza oceánica mesozoica en el norte de Costa Rica y el sur de Nicaragua.- Rev. Geol. Amér. Central, 14: 105-107.

ASTORGA,A., 1994: El Mesozoico del sur de América Central: consecuencias para el origen y evolución de la Placa Caribe.- Profil, 7: 171-233. 
APPEL, H., WÖRNER, G., ALVARADO, G.E., RUNDLE, C. \& KUSSMAUL, S., 1994: Age relations in igneous rocks from Costa Rica.- Profil, 7: 63-69.

AZÉMA, J. \& TOURNON, J., 1980: La péninsule de Santa Elena, Costa Rica: un massif ultrabasique charrié en marge pacifique de l'Amérique Centrale, Costa Rica.- Comptes Rendus de L'Academie des Sciences des Paris, 290: 9-12.

AZÉMA, J., GLAÇON, G., TOURNON, J. \& VILA, J.-M., 1979: Precisiones acerca del Paleoceno de Puerto Quépos y sus alrededores, provincia de Puntarenas, Costa Rica.- Inf. Sem. IGN 1978, 2: 77-78.

AZÉMA, J., GLAÇON, G., TOURNON, J., 1981: Nouvelles données sur le Paléocène à foraminiféres planctoniques de la bordure pacifique de la bordure pacifique de Costa Rica, Amérique Centrale.- C.R. Som. Soc. Som. Socieété Geéologique de France, 3: 85-88.

AZÉMA , J., ORIGLIA, I., TOURNON, J. \& DE WEVER, P., 1982: Nouvelles données sur la présence de Crétacé Moyen au sein des formations volcano-sedimentaires de l'autochtone relatif de la péninsule de Santa Elena (Costa Rica, Amérique Centrale).- 9a Réunion annuelle des Sciences de la Terre, Paris 1982. Société Géologique de France, 1(2): 173-179.

AZEMA, J., BUTTERLIN J., TOURNON, J. \& DE WEVER, P., 1983: Presencia de material volcano-sedimentario de edad Eoceno Medio en la Península de Osa (Provincia de Puntarenas, Costa Rica).$10^{\circ}$ Conferencia.; Geología del Caribe, Cartagena, Colombia.

AZEMA, J., BOURGOIS, J., BAUMGARTNER, P.O., TOURNON, J., DESMET, A. \& AUBOUIN, J., 1984: A tectonic crosssection of the Costa Rican Pacific littoral as a key to the structure of the landward slope of the Middle America Trench of Guatemala.- Initial Reports of the Deep Sea Drilling Project, 84: 831-849.

AZÉMA, J., BURGOIS, J., TOURNON, J., BAUMGARTNER, P.O. \& DESMET, A., 1985: L'Orogène pré-sénnonien supérieur de la marge pacifique du Costa Rica (Amérique Centrale).- Bull. Soc. Géol. France, 1(2): 173-179.

BARR, K.W. \& ESCALANTE, G., 1969: Contribución al Esclarecimiento de la Edad del Complejo de Nicoya, Costa Rica.- Publicaciones Geológicas ICAITI, 2: 43-47, Guatemala.

BAUMGARTNER, P.O, 1984: El complejo ofiolítico de Nicoya (Costa Rica): Modelos estructurales analizados en función de las edades de los Radiolarios (Calloviense a Santoniense).- In: SPRECHMANN, P. (ed.): Manual de Geología de Costa Rica.San José, Ed. UCR, 115-123.

BAUMGARTNER, P.O., 1986: Discovery of subduction-related mélange on Caño Island and Osa Peninsula (Pacific, Costa Rica, Central America).- [Abstract] Réunion annuelle des Sciences de la Terre, 1 lème, Clermond-Ferrand, France, 12.

BAUMGARTNER, P.O., 1987: Tectónica y sedimentación del Cretácico Superior en la zona pacifífica de Costa Rica (América Central).In: J.M. BARBARIN, J.M., GURSKY, H.-J., \& MEIBURG, P., (eds.): El Cretácico de México y América Central (resúmenes).Facultad de Ciencias de la Tierra, U.A.N.I., Linares-Mexico, II: 251-260.

BAUMGARTNER, P.O. \& DENYER, P., 2006: Evidence for middle Cretaceous accretion at Santa Elena Peninsula (Santa Rosa Accretionary Complex), Costa Rica.Geologica Acta, 4(1-2): 179-191. 
BAUMGARTNER, P.O., MORA, C.R., BUTTERLIN, J., SIGAL, J., GLACON, G., AZÉMA, J. \& BURGOIS, J., 1984: Sedimentación y paleogeografía del Cretácico y Cenozoico del litoral pacífico de Costa Rica.- Rev. Geol. Amér. Central, 1: 57-136.

BUCHS, D.M. \& BAUMGARTNER, P.O., 2007: Comment "From seamount accreation to tectonic erosion: formation of Osa Mélange and the effects of Cocos Ridge subduction in southern Costa Rica" by P. VANNUCCHI P., et al.- Tectonics, 26, TC3009, doi:10.1029/2006TC002032.

BAUMGARTNER, P.O., FLORES, K., BANDINI, A.N., GIRAULT, F. \& CRUZ, D., 2008: Upper Triassic to Cretaceous radiolaria from Nicaragua and northen Costa Rica - the Mesquito Composite Oceanic Terrane.- Ofioliti, 33(1): 1-19.

BECCALUVA, L., CHINCHILLA-CHAVES, A.L., COLTORTI, M., GIUNTA, G., SIENA, F. \& VACCARO, C., 1999: Petrological and structural significance of the Santa Elena-Nicoya Ophiolitic Complex in Costa Rica and geodynamic implications.- European Journal of Mineralogy, 11: 1091-1107.

BELLON, H. \& TOURNON, J., 1978: Contribution de la géochronologie $\mathrm{K} /$ Ar á l'étude du magmatisme de Costa Rica, Amérique Central.- Bull. Soc. Géol. France, 20/6: 955-959.

BERRANGÉ, J.P. \& THORPE, R.S., 1988: The geology, geochemistry and emplacement of the Cretaceous-Tertiary ophiolitic Nicoya Complex of the Osa peninsula, southern Costa Rica.- Tectonophysics, 147: 193-220.

BERRANGÉ, J.P., BRADLEY D.R. \& SNELLING N.J., 1989: K/Ar dating of the ophiolitic Nicoya Complex of the Osa Peninsula, southern Costa Rica.- Jour South Amer. Earth Sciences, 2(1): 49-59.
BROWN, G.C. \& MUSSETT, A.E., 1981: The inaccessible Earth.- 325 págs. Allen and Unwin, Londres.

BUCHS, D.M. \& BAUMGARTNER, P.O., 2003: The Osa-Caño Accretionary Complex (Southern Costa Rica): sedimentary processes in the Middle American Trench recorded in an emerged Eocene-Miocene accretionnary prism.- [Abstract] $11^{\text {th }}$ Swiss Meeting of Sedimentologist, Fribourg, 35.

BUCHS, D.M. \& STUCKI, 2001: Etude géologique, éochmique et structurale du complexe d'accrétion de la péninsule d'Osa, Costa Rica.- 103 págs. Univ. de Lausanne, Suisse [Diplome thesis].

BUNDSCHUH, J. \& ALVARADO, G.E. (eds.), 2007: CentralAmerica: Geology, Resources and Hazards.- lix +1311 págs. Taylor \& Francis, Londres Vol. $1+2$.

BURGOIS, J., AZÉMA, J., BAUMGARTNER, P.O., TOURNON, J., DESMET, A. \& AUBOUIN, J., 1984: The Geologic history of the Caribbean-Cocos plate boundary with special reference to the Nicoya Ophiolite Complex (Costa Rica) and Deep Sea Drilling Project results (legs 67 and 84 of Guatemala): a synthesis.Tectonophysics, 108: 1-32.

BURKE, K., FOX, P.J. \& SENGOR, A.M.C., 1978: Buoyant ocean floor and the evolution of the Caribbean.- J. Geoph. Res. 83: 1255-1258.

CALERO, A., 1987: Geología del Cerro Hortigal y alrededores, provincia Puntarenas, Costa Rica.- 50 págs. Univ. Costa Rica, San José [Inf. Campaña Geol.].

CASE, J.E., HOLCOMBE, T.L. \& MARTIN, R.G., 1984. Map of geologic provinces in the Caribbean region.- En: BONINI, W.E., HARGRAVES, R.B. \& SHAGAM, 
R. (eds.): The Caribbean-South American plate boundary and regional CaribbeanSouth American plate and regional tectonics. Geological Society of America Mem., 162, 1-30, map, scale 1: 5000000.

COLEMAN, R.G., 1977. Ophhiolites. Ancient Oceanic Lithosphere? -229 págs. SpringerVerlag, Berlin.

DE BOER, J., 1979: The outer arc of the Costa Rican Orogen (oceanic basement complexes of the Nicoya and Santa Elena peninsulas.Tectonophysics, 56(3/4): 221-259.

DENGO, G., 1962a: Tectonic-igneous sequence in Costa Rica.- In: Petrologic studies. Volume in honor of A.F Buddington, Geol. Soc. Am., 133-161.

DENGO, G., 1962b. Estudio Geológico de la Región de Guanacaste, Costa Rica. San José-Costa Rica.- 112 págs. IGN, San José.

DENYER, P. \& ARIAS, O., 1993: Geología del norte de la península de Nicoya, Costa Rica.- Rev. Geol. Amér. Central, 16: 69-84.

DENYER, P. \& BAUMGARTNER, P.O., 2006: Emplacement of Jurassic-Lower Cretaceous radiolarites of the Nicoya Complex (Costa Rica).- Geologica Acta, 4 (1-2): 203-218.

DENYER, P., BAUMGARTNER, P.O. \& GAZEL, E., 2006: Characterization and tectonic implications of MesozoicCenozoic oceanic assemblages of Costa Rica and Western Panama.- Geologica Acta, 4 (1-2): 219-235.

DE METS, C., GORDON, R.G., ARGUS, D.F. \& STEIN, S., 1990: Current plate motions.Geoph. Jour. International, 101: 425-478.

DESMET, A., TOURNON, J., AZÉMA, J. \& BOURGOIS, J., 1985: Le matériel ophiolitique foré du Leg 84, (fosu du Guatemala) et les ophiolites du massif de Santa Elena (Costa Rica): Comparaison pétrologique et géochimique.- Bull. Soc. Géol. France, 1(3): 309-328.

DE WEVER, P., AZÉMA, J, TOURNON, J. \& DESMET, A., 1985: Découverte de matériel océanique du Lias-Dogger inférieur dans la péninsule de Santa Elena (Costa Rica, Amérique Centrale).- Comptes Rendus de L'Academie des Sciences des Paris, 300(15): 759-764.

DI MARCO, G., 1994: Les terrains accrétés du Sud du Costa Rica: Evolution tectonostratigraphique de la marge occidentale de la plaque Caraïbe.- Mémories de Géologie (Lausanne), 20: 1-184.

DI MARCO, G., BAUMGARTNER, P. O. \& CHANNELL, J.E.T., 1995: Late Cretaceous-early Tertiary paleomagnetic data and a revised tectonostratigraphic subdivision of Costa Rica and western Panama.- In: MANN, P. (ed.) Geological and tectonic development of the Caribbean Plate Boundary in Southern Central America.- Geol. Society Amer. Bull. Special Paper, 295: 1-27.

DISERENS M-O., 2002: Upper Cretaceous and Paleogene Radiolarian Biostratigraphy of Southern Costa Rica; Radiolarian faunas from the Rincon Block, Golfito and Burica terranes, Osa-Cano Accretionary Complex and Herradura Block.- 67 págs. Univer. Lausanne, Suisse [Diplome thesis].

DONNELLY, T.W., 1973: Late Cretaceous basalts from the Caribbean, a possible flood basalt province of vast size.- Eos Transactions American Geophysical Union, 54, 1004.

DONNELLY, T.W., 1994: The Caribbean Cretaceous basalt association: a vast igneous province that includes the Nicoya Complex of Costa Rica.- Profil, 7: 17-45. 
DUNCAN, R. A. \& HARGRAVES, R.B., 1984: Plate tectonic evolution of the Caribbean region in the mantle reference frame.- Geol. Soc. Amer. Bull. Memoir, 162: 81-93.

FLÜH, E.R., 1983)i: The Basic Igneous ComplexTrace of an Ancient Galapagos Hot Spot Aseismic Rigge?.- Zbl. Geol. Paläont., I, (3/4): 291-303, Stuttgart.

FRISCH, W., MESCHEDE, M. \& SICK, M., 1992: Origin of the Central America ophiolites: evidence from paleomagnetic results.Geol. Soc. Amer. Bull., 104: 1301-1314.

GALLI-OLIVIER, C., 1979: Ophiolite and island-arc volcanism in Costa Rica.- Geol. Soc. Amer. Bull. 90(1): 444-452.

GAZEL, E., DENYER, P. \& BAUMGARTNER, P.O., 2006: Magmatic and geotectonic significanse of Santa Elena Peninsula, Costa Rica.- Geologica Acta, 4 (1-2): 193-202.

GELDMACHER, J., HANAN, B.B., BLICHERT-TOFTl, J., HARPP, K., HOERNLE, K., HAUFF, F., WERNER, R. \& KERR, A.C., 2003: Hafnium isotopic variations in volcanic rocks from the Caribbean Large Igneous Province and Galápagos hot spot tracks.- Geochemistry, Geophysics, Geosystems, 4 (7), 1062, doi: 10. 1029/2002GC000477.

GOOSSEENS, P.J., ROSE, W.I. \& FLORES, D., 1977: Geochemistry of tholeiites of the Basic Igneous Complex of northwestern South America.- Geological Society of America Bulletin 88: 1711-1720.

GOSE, W.A., 1983: Late Cretaceous-Early Tertiary tectonic history of Southern Central America.- J Geophys. Res, 88: 10 585-10 592.

GURSKY, H.J., 1984: Verbreitung, fazies und geologische geschichtre der sedimentgesteine, insbesondere der radiolarite, im opiolithisschen Nicoya Komplex (OberJura bis Alt- Tertiär von Costa Rica).- 394 págs. Univ. Marburg [Tesis Ph.D].

GURSKY, H.-J., 1994: The oldest sedimentary rocks of South Central America: the radiolarian cherts of the Nicoya Ophiolite Complex (?Early Jurassic to Late Cretaceous).- Profil, 7: 265-277.

GURSKY, H.-J \& SCHMIDT-EFFING, R., 1983: Sedimentology of radiolarites within the Nicoya Ophiolite Complex, Costa Rica, Central America.- Dev. Sedimentol. 36: 127-142.

GURSKY, H.-J., SCHMIDT-EFFING, R., STREBIN, M. \& WILDBERG, H., 1982: The ophiolite sequence in northwestern Costa Rica (Nicoya Complex): outlines of stratigraphical, geochemical, sedimentological, and tectonical data.- Actas V Congreso Latinoamericano de Geología, Buenos Aires, 3: 607-619.

GURSKY, H.-J., GURSKY, M., SCHMIDTEFFING, R. \& WILDBERG, H., 1984: Karten zur Geologie von Nordwest-Costa Rica (Mittelamerika) mit Erläuterungen.- Geologica et Palaeontologica, 18: 173-182.

GURSKY, H.-J. \& GURSKY, M., 1988: Thermal alteration of chert in the ophiolite basement of Southern Central America.- In: HEIN, J.R., OBRADOVIC, J. (eds.): Siliceous deposits of the Pacific and Tethys Regions.Springer-Verlag, New York: 217-233.

GURSKY, M.M., 1988: Estructuras tectónicas de edad cretácica y terciaria en la Peninsula de Nicoya (Costa Rica) y su significado geotectónico.- In: BARBARIN, J.M., GURSKY, H.-J., MEIBURG, P. (eds.): El Cretácico de México y América Central.Actas Facultad de Ciencias de la Tierra. Universidad Autónoma de Nuevo León. Linares (México), 261-265. 
HARRISON, J.V., 1953: The geology of the Santa Elena Peninsula in Costa Rica.- Seventh Pacific Scientific Cong. Proc., 2: 102-114.

HAUFF, F., HOERNLE, K. \& BOGAARD, P., 2000: Age and geochemistry of basaltic complexes in western Costa Rica: Contributions to the geotectonic evolution of Central America.- Geochemistry, Geophysics, Geosystems (G3), 1(5), doi 10.1029/1999GC000020.

HAUFF, F., HOERNLE, K., SCHMINCKE, H.-U. \& WERNER, R., 1997: A mid Cretaceous origin for the Galápagos hotspot: volcanological, petrological and geochemical evidence from Costa Rica oceanic crustal fragments.- Geologische Rundschau, 86: 141-155.

HENNINGSEN, D., 1966: Notes on stratigraphy and paleontology of upper Cretaceous and Tertiary sediments in southern Costa Rica.American Association Petroleum Geology Bulletin, 57: 33-47.

HENNINGSEN, D. \& WEYL, R., 1967: Ozeanische kruste im Nicoya-Komplex von Costa Rica (Mittelamerika).- Geologischen Rundschau, 57:33-47.

HESS, H.H., 1955: Serpentines, orogeny and epeirogeny. In: POLDERVAART, A. (ed.): Crust of the earth.- Geol. Soc. Amer. Spec. Paper, 62: 1-762.

HEY, R. 1977: Tectonic evolution of the CocosNazca spreading center.- Geol. Soc. Amer. Bull. 88: 1404-1420.

HOERNLE, K. \& HAUFF, F., 2007: Oceanic igneous complexes.- In: BUNDSCHUH J. \& ALVARADO, G.E.: Central America: Geology, Resources and Hazards. Taylor \& Francis, London, 523-547.
HOERNLE, K., HAUFF, F. \& VAN DEN BOGAARD, P., 2004: 70 m.y. history (139-69 Ma) for the Caribbean large igneous province.- Geology, 32(8): 697-700.

HOERNLE, K., VAN DEN BOGGARD, P., WERNER, R., LISSINA, B., HAUF, F., ALVARADO, G.\&GARBE-SCHÖNBERG, D., 2002: Missing history (16-71 Ma) of the Galápagos hotspot: Implications for the tectonic and biological evolution of the Americas.- Geology, 30(9): 795-798.

HOWELL, D.G., JONES, D.L. \& SCHERMER, E.R., 1985: Tectonostratigraphic terranes of the Circum-Pacific region.- In: HOWELL, D.G. (ed.): Tectonostratigraphic terranes of the Circum-Pacific region. Circum-Pacific Council, Ener. Min. Res. Earth Sciences Series, 1: 3-30.

ITURRALDE-VINENT, M. (ed), 1996. Ofiolitas y Arcos Volcánicos de Cuba (Cuban Ophiolites and Volcanic Arcs).- IUSG/ UNESCO, IGCP Project 364, 1: 1-254.

ITURRALDE-VINENT, M. \& MACPHEE, R.D.E., 1999: Paleogeography of Caribbean region: Implications for Cenozoic Biogeography.- Bull. Am. Museum of Natural History 238: 1-95.

KARIG, D.E. \& SHARMAN, III, G.F., 1975: Subduction and accretion in trenches.Geol. Soc. Amer. Bull., 86: 377-389.

KERR, A.C., TARNEY, J., MARRINER, G.F., NIVIA, A. \& SAUNDERS, A.D., 1997: The Caribbean-Colombian Cretaceous Igneous Province: The Internal Anatomy of an Ocanic Plateau.- In: MAHONEY, J.J. \& COFFIN, M.F. (eds.): Large Igneous Provinces. Continental, Oceanic, and Planetary Flood Volcanism. Geophys. Monograph, 100: 123-144. 
KRIZ, S., 1990: Tectonic evolution and origin of the Golfo Dulce Placers in southern Costa Rica.- Rev. Geol. Amér Central, 11: 27-40.

KUIJPERS, E., 1979: La geología del Complejo Ofiolítico de Nicoya, Costa Rica.- Inf. Sem. IGN, 1979(2): 15-75.

KUIJPERS, E.P., 1980: The geologic history of the Nicoya Ophiolite Complex, Costa Rica and its geotectonic significance.Tectonophysics, 68: 233-255.

LE MAITRE, R.W. (ed.), 1989: A classification of igneous rocks and glossary of terms.- 193 págs. Blackwell Scientific Publications, Oxford.

LEW, L.R., 1983: The geology of Osa peninsula, Costa Rica: observation and speculations about the evolution of part of the outer arc of the Southern Central American Origen.128 págs., Ph.D. thesis, Pennsylvania State Univ.

LLOYD, J.J., 1963: Tectonic History of the South Central-American Origen.- American Association Petroleum Geology Memory 2: $88-100$.

LUNDBERG, N., 1982: Evolution of the slope landward of the Middle America Trench, Nicoya Peninsula, Costa Rica.In: LEGGET, J.K. (ed.), Trench-Forearc Geology: Sedimentation and Tectonics on Modern and Ancient Active Plate Margins. Geological Society London, S p e c i a 1 Publication, 10: 131-150.

MALAVASSI, E., 1967: Informe geológico de la hoja Candelaria.- 16 págs. Min. Econ. Ind. Com.[Informe interno].

MALFAIT, B.T. \& DINKELMAN, M.G., 1972: Circum-Caribbean tectonic and igneous activity and the evolution of the Caribbean plate.- Geol. Soc. Amer. Bull. 83: 2512-272.
MESCHEDE, M. \& FRISCH, W., 1994: Geochemical characteristics of basaltic rocks from the Central American ophiolites.Profil, 7: 71-85.

MESCHEDE, M. \& FRISCH, W., 1998: A plate tectonic model for the Mesozoic and Early Cenozoic history of the Caribbean plate.Tectonophysics, 296: 269-291.

MIEM (Ministerio de Industria, Economía y Comercio), 1982: Mapa Geológico de Costa Rica.- 9 maps. Scale 1:200 000. Instituto Geográfico Nacional. San José, Costa Rica.

MOORES, E.M., 1982: Origen and emplacement of ophiolites.- Reviews of Geophysicas and Space Physics, 20: 735-760.

MULLEN, E.D., 1983. Mn/TiO2/Pe2O5: a minor element discriminat for basaltic rocks of oceanic enviroments and its implications for petrogenesis.- Earth and Planetary Science Letters, 63: 53-62.

NUR, A. \& BEN-AVRAHAMA, Z., 1977: Lost Pacifica continent.- Nature 270: 41-43.

PEARCE, J.A., NORRY, M.J., 1979: Petrogenetic implications of $\mathrm{Ti}, \mathrm{Zr}$, $\mathrm{Y}$, and $\mathrm{Nb}$ variations in volcanic rocks.- Contribution Mineral. Petrol., 69: 33-47.

PICHLER, H. \& WEYL, R., 1973: Petrochemical aspects of Central American. -Geolo. Rundschau, 62(2): 357-396.

RAGAZZI, C., 1996: Petrologia e geologia del Complesso Ofiolitico di Nicoya-Santa Elena (Costa Rica).- 115 págs. Università degli Studi di Ferrara [Tesis Ph.D].

RANERO, C.R \& VON HUENE, R., 2000: Subduction erosion along the Middle America convergent margin.- Nature, 404(6779): 748-752. 
ROBERT, J.R., 1944: Magnese deposits in Costa Rica.- Bull. U.S. Geol. Survey, $935(\mathrm{H}), 387-414$.

ROBERTS, J.R. \& IRVING, E.M., 1957: Mineral deposits of Central America.U.S. Geological Survey Bulletin, 1034: $1-205$.

ROMANES, J., 1912a: Geological notes on the Peninsula of Nicoya.- Geol. Mag. 9: 258-265.

ROMANES, J., 1912b: Geology of a part of Costa Rica.- Geol. Soc. London Quat. Jour., 68: 103-139.

SALEEBY, J.B., 1982: Polygenetic Ophiolite Belt of the California Sierra Nevada: Geochronological and Tectonostratigraphic Development.- J. Geophys. Res., 87: 1803-1824.

SAPPER, K., 1905: Ueber Gebirgsbau und boden des sudlichen mittelamerika Pettermanns geographische, 32: 1-82.

SAPPER, K., 1937: Mittleamerika. Handbuch der regionales Geologie.- 160 págs., Heildeberg, Steinman und Wilckens.

SCHMIDT-EFFING, R., 1979: Alter und Genese des Nicoya-Komplexes, einer ozeanischen Palaokruste (Objura bis Eozan) im sudlichen Zentral-Amerika. -Geol. Rundschau, 68(2): 457-494.

SCHMIDT-EFFING, R., 1980a: Rasgos fundamentales en la historia del Complejo de Nicoya (América Central Meridional).Brenesia, 18: 231-252.

SCHMIDT-EFFING, R., 1980b: Radiolarien der Mittel-Kreide aus dem Santa Elena-Massiv von Costa Rica.- Neves Jahrbuch Geologie und Pläontologie, 160(2): 241-257.

SEARS, J.D., 1919: Deposits of manganese ore in Costa Rica and Panama.- U.S. Geological Survey Bulletin 710-C, 61-91.
SEELY, D.R., VAIL, P.R., WALTON, G.G., 1974. In: BURK, C.A. \& DRAKE, C.L. (eds.): The geology of continental margins Continental margins Trench slope model. Springer-Verlag, New York, 249-260.

SEELY, D.R., 1979: The evolution of structural highs bordering major forearc basins. In: WATKINS J.S., MONTADERT, L., \& DICKENSON, P.W. (eds.): Geol. Geophys. Inv. cont. margins, 29: 245-260.

SHYPLEY, T.H., LADD, J.W., BUFFLER, R.T. \& WATKINS, J.S., 1982: Tectonic processes along the Middle America Trench. In: LEGGETT, J.K. (ed.): Forearc geology: sedimentation and tectonics on modern and ancient plate margins. 95-106, Oxford.

SICK, M., 1989: Paleomagnetism of the Ophiolite Complex from the Southern Middle American Landbridge (Costa Rica and Western Panamá).- Geowissenschaftliche Abhandlungen, 4: 1-108.

SINTON, C. W., DUNCAN, R.A. \& DENYER, P., 1997: Nicoya Peninsula, Costa Rica: A single suite of Caribbean oceanic plateau magmas.- J. Geoph. Res., 102: 15507-15520.

STEINMANN, G., 1905: Geologische Beobachtungen in den Alpen. II. Die Schardtsche Ueberfaltungstheorie un die geologische Bedeutung der Tiefseeabsätze und der ophiolithischen Massengesteine.- Ber. Naturfor. Gesellsch. Freiburg i. B., 16: 18-67.

STEINMANN, G., 1927: Die ophiolithischen Zonen in der mediterranean Kettengebirgen.- 14th Internat. Geol. Congr., Madrid, 2: 638-667.

TOURNON,J.1984:MagmatismesduMesozoique á l' actuel en Amerique Centrale: L' exemple de Costa Rica, des ophiolites aux andesites.- 335 págs. University Pierre and Marie Curie, Paris [Tesis Ph.D]. 
TOURNON, J., 1994: The Santa Elena Peninsula: an ophiolitic nappe and a sedimentary volcanic relative autochthonous.- Profil, 7: 87-96.

TOURNON, J. \& ALVARADO, G.E., 1997: Mapa Geológico de Costa Rica.- 79 págs, map scale 1:500 000. Editorial Tecnológica de Costa Rica, Cartago-Costa Rica.

TOURNON, J. \& AZÉMA, J., 1980: Sobre la estructura y la petrología del macizo ultrabásico de Santa Elena (provincia de Guanacaste, Costa Rica).- Inf. Sem. IGN, 1980(I): 17-54.

TOURNON, J., SEYLER, M. \& ASTORGA, A, 1995: Les peridotites du Rio San Juan (Nicaragua et Costa Rica): jalons possibles d'une suture ultrabasique E-W en Amerique Centrale meridionale.- Comptes Rendus de l'Academie des Sciences, 320(8): 757-764.

VANNUCCHI, P. FISHER, D.M. \& GARDNER, T.W., 2007: Reply to comment by David M. Buchs and Peter O. Baumgartner on "From seamount accreation to tectonic erosion:formation of Osa Mélange and the effects of Cocos Ridge subduction in southern Costa Rica".- Tectonics 26, TC3010, doi:10.1029/2007TC002129.

VANNUCCHI, P. FISHER, D.M. BIER, S. \& GARDNER, T.W., 2006: From seamount accretion to tectonic erosion: Formation of Osa Mélange and the effects of Cocos Ridge subduction in southern Costa Rica.- Tectonics 25, TC2004. doi: 10.1029/2005TC001855.

VON HUENE, R., BIALAS, J., FLUEH, E.R., COPP, B., CSERNOK, T., FABEL, E., HOFFMAN, J., EMEIS, K., HOLLER,
P., JESCHKE, G., LEANDRO, G., PEREZ FERNANDEZ, I., CHAVARRIA, S.J., FLOREZ, H.A., ESCOBEDO, Z.D., LEON, O.R. \& BARRIOS, L., 1995: Morphotectonics of the Pacific convergent margin of Costa Rica, in geologic and tectonic development of the Caribbean plate boundary in southern Central America.- Geol. Soc. Amer. Sp. Paper, 295: 291-308.

WEBBER, B.N., 1942: Manganese deposits in Costa Rica, Central America. Amer.- Inst. Min. Metallurg. Eng. Techn. Publ., 144, 339-345.

WEYL, R., 1961: Die Geologie Mittelamerikas.226 págs., Berlin (Borntraeger).

WEYL, R., 1965: Erdgeschichte und Landschaftsbild in Mittelamerika.- 175 págs., Frankfurt.

WEYL, R., 1969: Magmatische Förderphasen und Gesteinschemismus in Costa Rica (Mittelamerika).- N. Jb. Geol. Paläont. Mh., 7: 423-446.

WIDBERG, H.G.H., 1984: Der Nicoya Komplex, Costa Rica, Zentralamerika: Magmatismus und genese eines polymagmatischen Ophiolith-Komplexes.- Münster Forschungsschwerpunkte Geologisch Paläontologisches, 62: 1-123.

WILDBERG, H.G.H., GURSKY, H.-J., SCHMIDT-EFFING, R. \& STREBIN, M., 1981: Der OphiolithKomplex der Halbinsel Nicoya, Costa Rica, Zentralamerika.- Zbl. Geol. Paläont., 1: 195-209.

WILSON, M., 1989: Igneous Petrogenesis.- 466 págs., Unwing Hyman, London. 
